\title{
A muscle stem cell for every muscle: variability of satellite cell biology among different muscle groups
}

\author{
Matthew E. Randolph ${ }^{\dagger}$ and Grace K. Pavlath* \\ Department of Pharmacology, Emory University, Atlanta, GA, USA
}

The human body contains approximately 640 individual skeletal muscles. Despite the fact that all of these muscles are composed of striated muscle tissue, the biology of these muscles and their associated muscle stem cell populations are quite diverse. Skeletal muscles are affected differentially by various muscular dystrophies (MDs), such that certain genetic mutations specifically alter muscle function in only a subset of muscles. Additionally, defective muscle stem cells have been implicated in the pathology of some MDs. The biology of muscle stem cells varies depending on the muscles with which they are associated. Here we review the biology of skeletal muscle stem cell populations of eight different muscle groups. Understanding the biological

OPEN ACCESS

Edited by:

Jaime J. Carvajal,

Centro Andaluz de Biología del

Desarrollo, Spain

Reviewed by:

Gabrielle Kardon,

University of Utah, USA

Cecilia Jimenez-Mallebrera,

Hospital Sant Joan de Deu, Spain

*Correspondence:

Grace K. Pavlath,

Department of Pharmacology, Emory

University, 1510 Clifton Road,

Room 5027, Atlanta, GA 30322, USA

gpavlat@emory.edu

tPresent address:

Matthew E. Randolph,

Children's Cancer Therapy

Development Institute, Fort Collins,

CO, USA

Received: 31 July 2015

Accepted: 21 September 2015

Published: 07 October 2015

Citation:

Randolph ME and Pavlath GK (2015)

A muscle stem cell for every muscle: variability of satellite cell biology

among different muscle groups.

Front. Aging Neurosci. 7:190.

doi: 10.3389/fnagi.2015.00190 variation of skeletal muscles and their resident stem cells could provide valuable insight into mechanisms underlying the susceptibility of certain muscles to myopathic disease.

Keywords: satellite cell, muscle, muscular dystrophy, muscle stem cell, hypaxial, epaxial, diaphragm, craniofacial

\section{Introduction}

Skeletal muscle is a highly organized tissue that comprises up to $40 \%$ of a human's body mass and is required for essential functions such as metabolism, locomotion and breathing (Janssen et al., 2000; MacIntosh et al., 2006). The human body contains approximately 640 unique skeletal muscles, each having distinct functions in human physiology. Multiple factors contribute to skeletal muscle diversity including embryologic origin, myogenic regulatory pathways, and functional/metabolic requirements. Muscle heterogeneity is further underscored by the variable sensitivity of specific subsets of skeletal muscles to numerous distinct genetic mutations that give rise to muscular dystrophies (MD; Hoffman et al., 1987; Monaco et al., 1988; Bione et al., 1994; Brais et al., 1998; Bonne et al., 1999; Nonaka, 1999; Emery, 2002; Robinson et al., 2005; Bonnemann et al., 2014; Vieira et al., 2014). Adult muscle stem cells, called satellite cells, have been implicated in the pathology of some MDs (Table 1) and may contribute to the variable muscle sensitivity observed in some dystrophies.

Skeletal muscles are composed of myofibers, large syncytial cells containing hundreds of postmitotic myonuclei. Juxtaposed between the basal lamina and the myofiber cell membrane, satellite cells reside at the periphery of skeletal myofibers (Mauro, 1961). Recent studies have demonstrated that satellite cells expressing paired box protein $7(\mathrm{Pax} 7)$ are the primary myogenic cell required for muscle regeneration (Lepper et al., 2011; Murphy et al., 2011; Sambasivan et al., 2011). The majority of knowledge concerning satellite cell biology arises from studies examining somitederived muscles such as the quadriceps, gastrocnemius, tibialis anterior (TA), soleus, extensor digitorum longus, plantaris, biceps, and deltoid muscles, which collectively represent less than $2 \%$ of all skeletal muscles. Intriguingly, satellite cells present in other muscle groups, including trunk, 
TABLE 1 | Muscular dystrophies (MDs) in which deficits in satellite cell function have been implicated in disease pathology.

\begin{tabular}{|c|c|c|c|c|c|}
\hline $\begin{array}{l}\text { Muscular } \\
\text { dystrophy }\end{array}$ & Affected muscles & $\begin{array}{l}\text { Mutant } \\
\text { gene(s) }\end{array}$ & Affected protein(s) & Altered SC function & Reference \\
\hline Duchenne & $\begin{array}{l}\text { shoulder, upper limb, } \\
\text { diaphragm, and calf }\end{array}$ & $D M D$ & Dystrophin & $\begin{array}{l}\text { Replicative exhaustion; } \\
\text { Proliferation; Postnatal } \\
\text { myofiber hypotrophy }\end{array}$ & $\begin{array}{l}\text { Blau et al., 1983; Webster and Blau, } \\
\text { 1990; Sacco et al., 2010; Jiang } \\
\text { et al., 2014; Duddy et al., } 2015\end{array}$ \\
\hline \multicolumn{6}{|l|}{ Limb girdle: } \\
\hline LGMD1B & upper limb, shoulder, & LMNA & Lamin A/C & Differentiation & Frock et al., 2006 \\
\hline LGMD2C & & $S G C G$ & $\gamma$-Sarcoglycan & \multirow{4}{*}{$\begin{array}{l}\text { Decreased number; Replicative } \\
\text { impairment? }\end{array}$} & \multirow[t]{4}{*}{ Higuchi et al., 1999} \\
\hline LGMD2D & & $S G C A$ & $\alpha$-Sarcoglycan & & \\
\hline LGMD2E & & $S G C B$ & $\beta$-Sarcoglycan & & \\
\hline LGMD2F & & $S G C D$ & $\delta$-Sarcoglycan & & \\
\hline LGMD2H & & TRIM32 & tripartite motif-containing 32 & Replicative senescence & $\begin{array}{l}\text { Kudryashova et al., 2012; } \\
\text { Mokhonova et al., } 2015\end{array}$ \\
\hline $\begin{array}{l}\text { EGMD2 } \\
\text { EGMD3 }\end{array}$ & $\begin{array}{l}\text { shoulder, upper limb, } \\
\text { and calf }\end{array}$ & LMNA & Lamin A/C & Differentiation & $\begin{array}{l}\text { Favreau et al., 2004; Frock et al., } \\
2006\end{array}$ \\
\hline EGMD1 & & $E M D$ & Emerin & Proliferation; Differentiation & $\begin{array}{l}\text { Frock et al., 2006; Meinke et al., } \\
2015\end{array}$ \\
\hline \multicolumn{6}{|c|}{ Facioscapulo-humeral } \\
\hline \multirow[t]{3}{*}{ FSHD1 } & \multirow[t]{3}{*}{$\begin{array}{l}\text { facial, shoulder, upper } \\
\text { arm, foot, and } \\
\text { pelvic-girdle }\end{array}$} & \multirow[t]{3}{*}{$\begin{array}{l}\text { Chrom. } 4 q 35 \\
\text { D4Z4 } \\
\text { contraction }\end{array}$} & $D \cup \times 4$ & Differentiation; Myoblast toxicity & $\begin{array}{l}\text { Kowaljow et al., 2007; Bosnakovski } \\
\text { et al., 2008a,b }\end{array}$ \\
\hline & & & DUX4c & $\begin{array}{l}\text { Proliferation; } \\
\text { Differentiation }\end{array}$ & $\begin{array}{l}\text { Bosnakovski et al., 2008a; Ansseau } \\
\text { et al., } 2009\end{array}$ \\
\hline & & & FSHD region gene 1 & $\begin{array}{l}\text { Proliferation; Differentiation; } \\
\text { Fusion }\end{array}$ & $\begin{array}{l}\text { Chen et al., 2011; Feeney et al., } \\
2015\end{array}$ \\
\hline Oculopharyngeal & $\begin{array}{l}\text { upper eyelid, EOM, } \\
\text { pharynx, tongue, upper } \\
\text { arms/legs }\end{array}$ & PABPN1 & $\begin{array}{l}\text { Poly adenosine binding } \\
\text { protein-nuclear one }\end{array}$ & $\begin{array}{l}\text { Proliferation } \\
\text { Differentiation }\end{array}$ & $\begin{array}{l}\text { Périé et al., } 2006 \\
\text { Apponi et al., } 2010\end{array}$ \\
\hline \multicolumn{6}{|l|}{ Congenital MD: } \\
\hline $\begin{array}{l}\text { Bethlem } \\
\text { Ullich }\end{array}$ & $\begin{array}{l}\text { upper and lower } \\
\text { arms/legs, neck, lumbar } \\
\text { paravertebral, } \\
\text { intercostals, thigh, } \\
\text { gluteus maximus }\end{array}$ & $\begin{array}{l}\text { COL6A1 } \\
\text { COL6A2 } \\
\text { COL6A3 }\end{array}$ & Collagen $6 \mathrm{~A}$ & Self-renewal & $\begin{array}{l}\text { Urciuolo et al., 2013; Gattazzo et al., } \\
2014\end{array}$ \\
\hline $\begin{array}{l}\text { Rigid spine } \\
\text { syndrome } \\
\text { related to } \\
\text { SEPN1 }\end{array}$ & $\begin{array}{l}\text { paravertebral, } \\
\text { intercostals, thigh, } \\
\text { gluteus maximus }\end{array}$ & SEPN1 & Selenoprotein $\mathrm{N}$ & $\begin{array}{l}\text { Decreased satellite cell } \\
\text { numbers; Proliferation; } \\
\text { Exhaustion of satellite cell } \\
\text { pool }\end{array}$ & Castets et al., 2011 \\
\hline
\end{tabular}

diaphragm, larynx, tongue, extraocular, masseter, and pharynx, deviate from the canonical biology of their limb counterparts. Here, we address the muscle-specific variability of satellite cell biology and postulate how this variability could contribute to muscle-specific sensitivities found in MDs.

\section{Limb Muscle Satellite Cells: Establishing the Canon}

Skeletal muscles of rodent hindlimbs are commonly used to study satellite cells as these muscles are easy to identify, dissect, collect, and manipulate experimentally. The skeletal muscles 


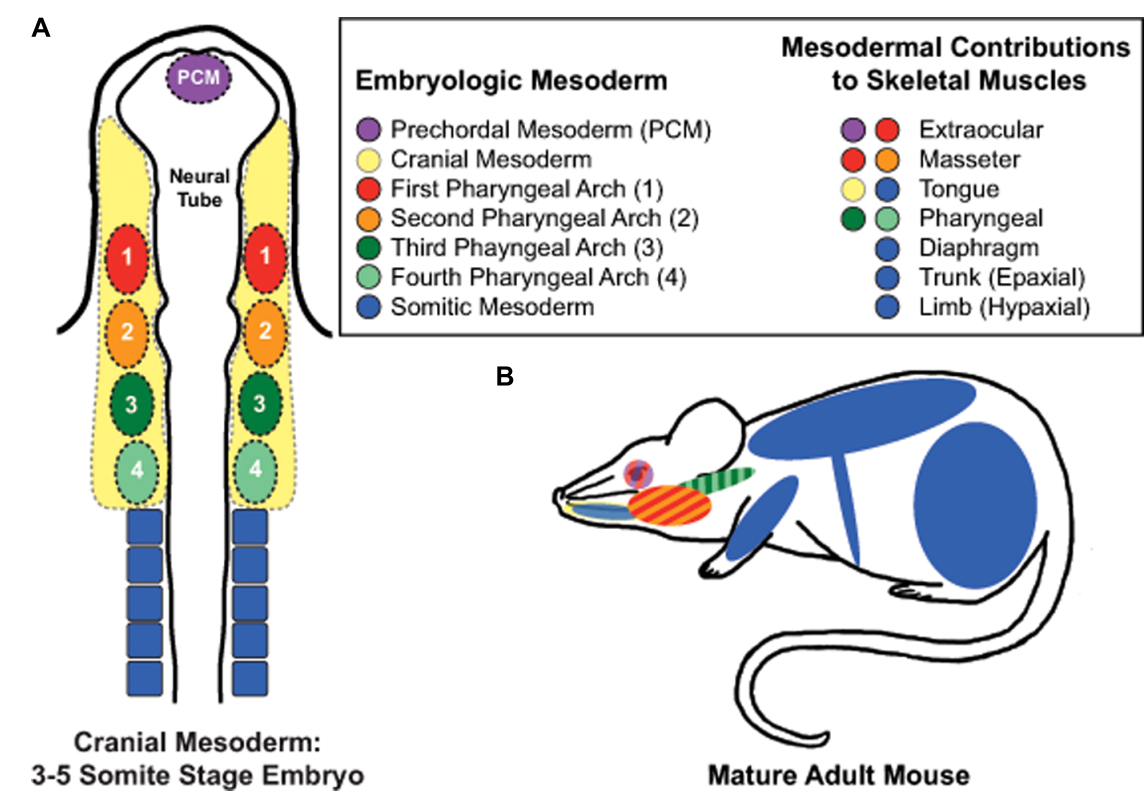

FIGURE 1 | Embryonic mesodermal contributions to adult skeletal muscles. (A) Schematic of mesodermal origins in a 3-5 somite stage mouse embryo. (B) Skeletal muscles of the trunk, limb, diaphgram, and tongue arise from somitic mesoderm. In contrast, the extraocular muscles (EOMs) arise from prechordal mesoderm and cranial paraxial mesoderm of the first pharyngeal arch; the masseter muscle from the first and second pharyngeal arches of the cranial paraxial mesoderm, and the pharynx from the third and fourth pharyngeal arches of the caudal paraxial mesoderm. Tongue muscles arise from both somitic and cranial mesoderm while developing within the niche of the cranial mesenchyme, which is supplied by all four pharyngeal arches.

of the limbs and abdomen arise from somitic mesoderm and are referred to as hypaxial muscles (Figure 1). They arise developmentally from the ventrolateral dermomyotome of the segmented paraxial mesoderm. In vivo and in vitro studies examining limb muscles provide fundamental insights into the mechanisms and regulatory pathways involved with skeletal muscle regeneration, muscle growth, and satellite cell biology.

Muscle regeneration is a robust and complex cellular process that restores injured muscle to a state that is morphologically and functionally similar to that of uninjured muscle (Figure 2; Abmayr and Pavlath, 2012). Regeneration of skeletal muscle occurs in two distinct phases: a degenerative phase and a regenerative phase (Rai et al., 2014). The main characteristics of the degenerative phase involve myofiber sarcolemmal damage or myofiber necrosis, followed by an influx of mononucleated inflammatory cells and an increase in fibroblasts (Mathew et al., 2011; Murphy et al., 2011; Rai et al., 2014). Factors released from damaged myofibers initiate an inflammatory response that recruits neutrophils, macrophages, and activates fibro/adipogenic progenitors to facilitate the removal of cellular debris and regulate muscle repair (McLennan, 1996; Lescaudron et al., 1999; Joe et al., 2010; Uezumi et al., 2010; Pallafacchina et al., 2013). The basal lamina remains intact acting as a scaffold for the next phase, muscle regeneration (Schmalbruch, 1976). Several molecular signals, such as growth factors, chemokines, and cytokines, are released which activate satellite cells both locally and systemically within the first $24-48 \mathrm{~h}$ following injury (Chang and Rudnicki, 2014; Rodgers et al., 2014). Myoblasts then terminally differentiate becoming post-mitotic myocytes, which then fuse with other myocytes or myofibers to regenerate or repair damaged myofibers. Thereby, new myonuclei are added to damaged or nascent myofibers (Abmayr and Pavlath, 2012). A subset of myogenic cells repopulate the satellite cell niche, thus maintaining and replenishing the quiescent satellite cell pool for subsequent rounds of regeneration ( Collins et al., 2005; Shinin et al., 2006).

The role of satellite cells in postnatal growth has also been studied in limb muscles. In mice, the first 3 weeks of neonatal growth results in a threefold increase in muscle mass during which the satellite cell population undergoes a significant reduction from $\sim 30 \%$ of myonuclei per myofiber down to $5 \%$, following fusion with neonatal muscles. Parallel increases in myonuclear numbers and cytoplasmic proteins occur up to postnatal day 21 (White et al., 2010). After postnatal day 21, satellite cells enter into a quiescent cellular state under the regulation of Notch signaling (Fukada et al., 2011), but myofiber size continues to increase without the addition of new myonuclei (White et al., 2010). Recent satellite cell ablation studies have also shown that myonuclear addition from satellite cells is dispensable for hypertrophic growth of limb muscles in the adult (McCarthy et al., 2011). Furthermore, satellite cells do not appear to be required for maintenance of most adult limb muscles. A recent satellite cell ablation study found that loss of $>90 \%$ of adult limb satellite cells failed to alter muscle size or myofiber type in five different limb muscles with aging (Fry et al., 2015). However, myonuclear addition does occur at a basal level in uninjured postnatal limb muscles and may be required for maintenance of extensor digitorum longus myofiber size with aging (Keefe et al., 


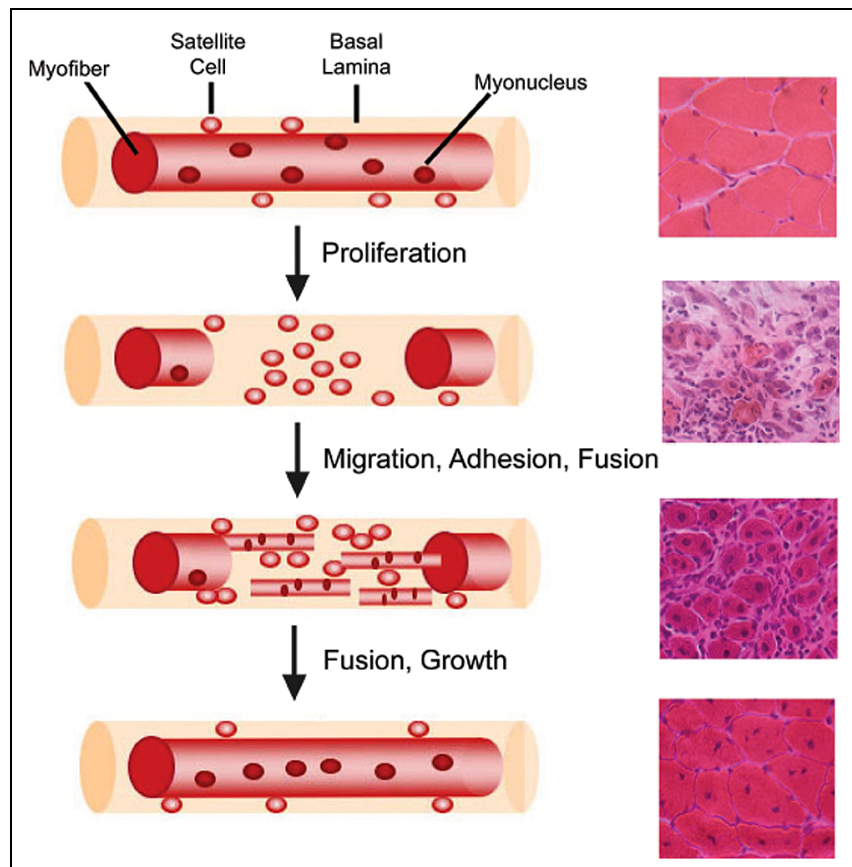

FIGURE 2 | Myofiber structure and cellular progression of myogenesis. Myofibers are surrounded by a basal lamina, underneath which lie satellite cells in close apposition to the myofiber. With injury, satellite cells proliferate and give rise to myoblasts, which differentiate, migrate, adhere, and fuse with one another to form multiple myotubes within the basal lamina scaffold. Myoblasts/myotubes fuse with the stumps of the surviving myofiber and myotubes also fuse with each other to repair the injured myofiber. Regenerated myofibers are identifiable by the presence of centrally located nuclei. Representative hematoxylin and eosin stained muscle cross-sections from chemically injured murine muscles are provided for each stage of muscle regeneration to illustrate the differential tissue morphology.

2015). Together, these studies suggest that the initial phase of postnatal muscle growth occurs with the addition of myonuclei from satellite cells, but maintenance of most adult limb muscle size is not dependent on satellite cells.

Regulatory genes involved in satellite cell biology have also been elucidated from studies of limb muscle. In adult skeletal muscle, quiescent satellite cells express Pax7, a transcription factor that specifies the myogenic lineage (Seale et al., 2000). Once activated, satellite cells exit cellular quiescence, enter the cell cycle, and begin progression through the myogenic lineage under the control of myogenic regulatory factors (MRFs), muscle-specific transcription factors of the basic-helix-loophelix (bHLH) class, including myogenic differentiation protein (MyoD), myogenic factor 5 (Myf5), myogenic regulatory factor 4 (Mrf4), and myogenin (Weintraub et al., 1991; Olson and Klein, 1994; Chang and Rudnicki, 2014). MyoD and Myf5 are expressed during the proliferative phase and regulate myogenic differentiation (Cooper et al., 1999; Valdez et al., 2000), while Mrf4 and myogenin are expressed upon terminal differentiation and exit from the cell cycle (Chang and Rudnicki, 2014).

Increasing evidence suggests that satellite cells within a muscle are heterogeneous (Motohashi and Asakura, 2014). Satellite cells containing high levels of Pax7 demonstrate slower proliferation rates, lower metabolism, and resistance toward differentiation, indicating a more "stem-like" phenotype compared to satellite cells with lower levels of Pax7 (Rocheteau et al., 2012). Various groups have also discovered distinct satellite cell subpopulations based on differential expression of other proteins including $\alpha 7$ integrin, $\beta 1$-integrin, c-met, CD34, calcitonin receptor, $\mathrm{C}-\mathrm{X}-\mathrm{C}$ chemokine receptor type 4 (CXCR4), M-cadherin, Myf5, neural cell adhesion molecule 1, syndecans 3 and 4, and vascular cell adhesion molecule 1 (Rosen et al., 1992; Cornelison and Wold, 1997; Beauchamp et al., 2000; Blanco-Bose et al., 2001; Cornelison et al., 2001; Tamaki et al., 2002; Sherwood et al., 2004; Fukada et al., 2007; Ikemoto et al., 2007; Kuang et al., 2007; Kafadar et al., 2009). While the mechanisms underlying satellite cell heterogeneity are still being elucidated, growing evidence suggests that satellite cell biology is also variable in a muscle-dependent manner, as discussed below.

\section{The 'Other' Somite-derived Muscles: Epaxial, Diaphragm, Internal Larynx, and Tongue Satellite Cells}

\section{Epaxial Satellite Cells}

Epaxial skeletal muscles include the deep muscles of the back. Similar to hypaxial muscle development, epaxial muscles arise from the dorsomedial dermomyotome of the segmented paraxial mesoderm (Figure 1; Christ and Ordahl, 1995; Burke and Nowicki, 2003). While the development of epaxial muscle is well studied (Munsterberg et al., 1995; Tajbakhsh et al., 1997; Borycki et al., 1999; Gustafsson et al., 2002; McDermott et al., 2005; Borello et al., 2006; L'Honore et al., 2010; Sato et al., 2010), the biological properties of adult epaxial satellite cells remain largely unknown. Mouse models expressing $n L a c Z$ under the control of the Pax3 promoter showed coexpression of Pax3 and Pax7 is retained in the majority of adult satellite cells of the deep ventral trunk muscles (Relaix et al., 2006). Pax3 expression was also maintained in cultured epaxial myoblasts, suggesting that Pax3 may contribute to both the quiescent and activated states of epaxial satellite cells (Relaix et al., 2006). How Pax3 contributes to adult epaxial satellite cell biology and the role of Pax3 in epaxial muscle regeneration remains to be determined, as well of other fundamental aspects of epaxial satellite cell biology and myogenesis.

\section{Diaphragm Satellite Cells}

The diaphragm muscle is composed of three distinct domains: crural muscle, costal muscle, and a central tendonous domain (Anraku and Shargall, 2009). Recent studies provide evidence that the muscle components arise from the lateral dermomyotome of the cervical somites while the central tendonous connective tissue arises from the pleuroperitoneal folds of lateral plate origin (Figure 1; Noden et al., 1999; Mootoosamy and Dietrich, 2002; Pickering and Jones, 2002; Babiuk et al., 2003; Brown et al., 2005; Merrell et al., 2015). Postnatally, diaphragmatic satellite cells differ from hypaxial muscle in that Pax3 expression is maintained along with Pax7 and Myf5 (Relaix et al., 2006; Day et al., 2007; Stuelsatz et al., 
2012). Recent studies indicate that satellite cell-derived myoblasts of the diaphragm behave differently than those of the hindlimb in vitro. Using the Nestin-GFP mouse model (Day et al., 2007) to identify self-renewal of myoblasts, Stuelsatz et al. (2014) found higher percentages of $\mathrm{GFP}^{+}$cells in diaphragm verses limb muscle cultures. In vitro clonal expansion assays revealed that diaphragmatic myoblasts proliferated similarly to those of hindlimb muscles (Chen et al., 2011; Stuelsatz et al., 2012), but myogenic differentiation of diaphragm cultures consistently reached maximum fusion indexes earlier than limb cultures (Stuelsatz et al., 2014). However, other studies demonstrated that diaphragmatic satellite cells undergo increased proliferation and decreased differentiation in vitro when compared to limb, trunk, and craniofacial muscles (Ippolito et al., 2012). The discrepancies in these studies evidence the need for further examination of diaphragmatic satellite cell biology. In vivo studies also indicate some interesting biology associated with diaphragmatic satellite cells. In vivo lineage tracing studies examining the contribution of diaphragmatic satellite cells to uninjured diaphragm muscles revealed continued addition of new myonuclei with age, yet myofiber size was not affected with satellite cell ablation (Keefe et al., 2015). One study in rats suggests that heterogeneity exists in the response of diaphragmatic satellite cells to the growth promoting stimuli provided by hemi-diaphragm denervation. By examining satellite cell numbers associated with various fiber types, this study found that only type IIx/b myofibers of the compensating non-denervated hemi-diaphragm showed significant increases in satellite cell numbers in both juvenile and adult mice, while no changes in number were associated with Type I or IIa myofibers (Kawai et al., 2012). Taken together, our current understanding of diaphragmatic satellite cell biology is still rudimentary and warrants further study, both in vivo and in vitro.

\section{Intrinsic Laryngeal Satellite Cells}

The intrinsic muscles of the larynx are critical for respiration, airway protection and vocalization and include the thyroarytenoid, posterior cricoarytenoid (PCA), and lateral cricoarytenoid muscles. The intrinsic laryngeal muscles arise from the occipital somites during development (Figure 1; Noden et al., 1999; Noden and Francis-West, 2006). In thyroarytenoid and PCA muscles, basal levels of myonuclear addition were discovered using BrdU lineage tracing, suggesting that uninjured laryngeal muscle contains a subset of proliferating satellite cells (Goding et al., 2005). In vitro studies also found increased proliferation rates associated with Erk1/2 phosphorylation in primary laryngeal muscle cultures compared to hindlimb cultures (Walz et al., 2008). In response to laryngeal denervation, laryngeal satellite cell activation and proliferation occurs in vivo within days following denervation (Kumai et al., 2007) with myonuclear addition occurring in all intrinsic laryngeal muscles analyzed (Shinners et al., 2006). Surprisingly, myogenic cells expressing MyoD and myogenin are still present in thyroarytenoid muscles 2 years post-denervation in humans, suggesting a unique prolonged regenerative potential in laryngeal muscle (Donghui et al., 2010). In spite of this, agerelated decreases in laryngeal satellite cell density and impaired regeneration of thyroarytenoid muscles occur (Malmgren et al., 2000; Lee et al., 2012). Together, these studies provide intriguing insights into intrinsic laryngeal satellite cells, but further studies are needed to elucidate the molecular and regulatory mechanisms underlying their distinct biology.

\section{Tongue Satellite Cells}

Tongue muscles arise from mixed mesodermal origins. The intrinsic muscles arise from the first occipital somite, while cranial paraxial mesoderm contributes to the formation of the exterior tongue muscles (Figure 1; Shuler and Dalrymple, 2001; Czajkowski et al., 2014). To date, knowledge of adult tongue muscle satellite cell biology is severely limited. A denervation study of the tongue muscle using ${ }^{3} \mathrm{H}$-thymidine to label proliferating cells revealed increased numbers of ${ }^{3} \mathrm{H}$-thymidine labeled myonuclei, which suggests fusion of proliferating satellite cells to the myofibers (McGeachie and Allbrook, 1978). Tonguederived myoblasts have been isolated, cultured and successfully differentiated into nascent myotubes in vitro, but the myogenic characteristics of these cells are yet to be directly studied (Ternaux and Portalier, 1993; LaFramboise et al., 2003).

\section{Craniofacial Satellite Cells: Extraocular, Masseter, and Pharyngeal}

\section{Extraocular Satellite Cells}

Extraocular muscles (EOMs) are responsible for rotation and movement of the eye and include the superior oblique, inferior oblique, superior rectus, inferior rectus, lateral rectus, and medial rectus muscles. EOM and their associated satellite cells differ from other skeletal muscles in that they arise from the prechordal and cranial paraxial mesoderm of the first pharyngeal arch during development (Figure 1; Couly et al., 1992; Noden and Francis-West, 2006). Early studies examining the effects of aging and dystrophic disease suggested EOM muscles are distinct from their hindlimb counterparts. Aging studies suggested that EOMs were preferentially spared with aging (Porter et al., 1998; Schoser and Pongratz, 2006), while studies examining EOM involvement in Duchenne, Becker, and some limb girdle MDs also showed a preferential sparing of these muscles (Kaminski et al., 1992; Emery, 2002). In addition, satellite cells of EOM have unique gene expression profiles in comparison to quiescent satellite cells of hindlimb muscles (Porter and Baker, 1996; Pacheco-Pinedo et al., 2009). EOM satellite cells also demonstrate distinct biological differences when compared to hindlimb satellite cells. In several species, EOM satellite cells chronically proliferate in vivo (McLoon and Wirtschafter, 2002a, 2003; Wirtschafter et al., 2004; Christiansen and McLoon, 2006), which may in part be due to a specific highly proliferative subpopulation (Kallestad et al., 2011). The transcription factor Pitx2 is expressed in postnatal EOM myogenic precursor cells that are of a $\mathrm{CD} 34^{+} / \mathrm{Sca} 1^{-} / \mathrm{CD} 31^{-} / \mathrm{CD} 45^{-}$lineage, which is thought to contribute to the proliferative properties of EOM satellite cells (Hebert et al., 2013). In addition, aged EOM satellite cells maintain proliferative and self-renewal abilities out to 24 months of age in vitro (Stuelsatz et al., 2014). Furthermore, 
global and orbital EOM satellite cells contribute new myonuclei to EOM myofibers in the absence of injury (McLoon and Wirtschafter, 2002a,b, 2003; Wirtschafter et al., 2004; Keefe et al., 2015). Together, these studies highlight satellite cell biology that is distinct from hindlimb satellite cells. Because of their proliferative and self-renewal propensities, EOM satellite cells have been proposed to be ideal candidates for use in cell-based therapies of myopathic disease (McLoon et al., 2007; Kallestad et al., 2011; Stuelsatz et al., 2014). However, in transplantation experiments in which EOM satellite cells were injected into the TA muscle of the hindlimb, EOM satellite cells successfully engrafted into the novel niche, but lost EOM-specific phenotypes such as expression of Myh13 and slow-tonic myosin (Sambasivan et al., 2009). These data suggested that the phenotypes of EOM satellite cells may be controlled by the niche. In support of this hypothesis, a recent study suggested that $\mathrm{PW} 1 / \mathrm{peg}^{+}$interstitial cells (PICs), which are present in higher numbers in EOM compared to the TA, provide a promyogenic environment that contributes to the resistance of both EOM satellite cells and myofibers to dystrophic and age-related disease (Formicola et al., 2014). Together, these data raise some intriguing questions. What roles do intrinsic and extrinsic mechanisms have on EOM satellite cell biology? Can such mechanisms be manipulated to improve the quality of life for individuals suffering from myopathic diseases? Studies are still needed to further elucidate the mechanisms contributing to the unique phenotypes of these satellite cells.

\section{Masseter Satellite Cells}

Adult masseter satellite cells arise from the first and second pharyngeal arches of the cranial paraxial mesoderm with contributions from the splanchnic mesoderm and express a unique transcription profile compared to hindlimb satellite cells (Figure 1; Kelly et al., 2004; Noden and Francis-West, 2006; Nathan et al., 2008; Sambasivan et al., 2009). Early in vivo studies demonstrated an impaired regenerative ability in masseter muscles compared to hindlimb muscle that was associated with a lower number of satellite cells during regeneration (Pavlath et al., 1998). Masseter satellite cells undergo prolonged periods of proliferation in vitro with a concurrent delay of differentiation onset (Ono et al., 2010), which potentially may contribute to the impaired regenerative response observed in acute injury to masseter muscle. In contrast, masseter satellite cells increase in number per myofiber with age while their proliferative capabilities decline ex vivo (Ono et al., 2010). What molecular pathways are involved with the age-associated increase in satellite cell numbers in masseter muscles verses the decrease in satellite cell numbers in other skeletal muscles? Little is known regarding the underlying molecular mechanisms driving the phenotypes of masseter satellite cells.

\section{Pharyngeal Satellite Cells}

Swallowing depends on the synchronous contraction of seven major muscles lining the nasal, oral, and laryngeal pharynxes to ensure propulsion of food and liquid from the oral cavity into the esophagus (Donner et al., 1985; Rubesin et al., 1987; Ekberg et al., 2009). Pharyngeal muscles arise from the cranial paraxial mesoderm of the third and fourth pharyngeal arches with contributions from splanchnic mesoderm (Figure 1; Kelly et al., 2004; Noden and Francis-West, 2006; Nathan et al., 2008). Pharyngeal muscles include the stylopharyngeus, palatopharyngeus, salpingopharyngeus, and the superior, middle, and inferior pharyngeal constrictor muscles (Dutta and Basmajian, 1960; Himmelreich, 1973; Donner et al., 1985; Rubesin et al., 1987; Ekberg et al., 2009). The inferior pharyngeal constrictor can be subdivided into the cricopharyngeus and the thyropharyngeus muscles (Donner et al., 1985; Rubesin et al., 1987; Ekberg et al., 2009). Recent in vivo and in vitro studies indicate that pharyngeal satellite cells have unique biological characteristics compared to hindlimb satellite cells. Pharyngeal muscles contain increased numbers of activated and proliferating satellite cells and contribute new myonuclei to pharyngeal myofibers in the absence of induced injury (Randolph et al., 2015). Additionally, in vitro clonal assays suggest a highly proliferative subpopulation of pharyngeal satellite cells could be contributing to the proliferative phenotype (Randolph et al., 2015). In vivo ablation studies indicated that satellite cells were required to maintain myonuclear numbers in certain pharyngeal muscles under basal conditions, suggesting that pharyngeal muscles undergo myonuclear turnover and require myonuclear addition from ongoing satellite cell myogenesis (Randolph et al., 2015). Could pathologic mutations enhance myonuclear turnover in pharyngeal muscles to such an extent that pharyngeal satellite cells could no longer adequately supply enough myonuclei to maintain homeostasis? Do disease-causing mutations impair the basal myogenic phenotype of pharyngeal satellite cells, potentially contributing to the pathological sensitivity of pharyngeal muscles observed in some MDs? These questions and many more remain to be addressed. However, several studies have examined pharyngeal satellite cell biology in the context of oculopharyngeal muscular dystrophy and will be discussed below.

\section{Could Variable Satellite Cell Biology Contribute to the Differential Susceptibility of Certain Muscles to Dystrophic Mutations?}

Muscular dystrophies are a group of degenerative muscle diseases due to mutations in proteins ranging in function such as sarcolemmal structure (Hoffman et al., 1987), nuclear envelope structure (Bione et al., 1994; Bonne et al., 1999; Mittelbronn et al., 2008), post-translational glycosylation (Bonnemann et al., 2014), and RNA binding (Brais et al., 1998; Kühn et al., 2009). Many mutations have been characterized in both skeletal muscle-specific and ubiquitously expressed genes, yet both manifest in muscular pathology. Intriguingly, each dystrophy affects a specific subset of skeletal muscles within the human body (Emery, 2002), suggesting that biological differences exist between individual muscles that predispose them to specific pathological etiologies.

Satellite cells have been implicated in the pathology of some MDs and may contribute to the variable muscle sensitivity observed in some dystrophies through several mechanisms 
(Table 1). For example, in response to chronic myofiber degeneration, satellite cells are subjected to multiple rounds of regeneration, which can "exhaust" the regenerative abilities of the satellite cell population over time (Webster and Blau, 1990; Decary et al., 2000; Morgan and Zammit, 2010; Sacco et al., 2010). Additionally, satellite cell impairment may occur early in the disease process if satellite cells express the mutant genes. Below we discuss the functional deficits in satellite cells observed in Duchenne MD (Blau et al., 1983; Webster and Blau, 1990; Sacco et al., 2010), Emery-Dreifuss MD (Favreau et al., 2004; Frock et al., 2006), facioscapulohumeral MD (Winokur et al., 2003; Barro et al., 2010), myotonic dystrophy (Furling et al., 2001; Thornell et al., 2009), oculopharyngeal MD (Périé et al., 2006), and some congenital MDs as well (Castets et al., 2011; Urciuolo et al., 2013).

\section{Duchenne Muscular Dystrophy}

Duchenne muscular dystrophy (DMD) is an early onset childhood X-linked disease associated with the absence of dystrophin (Hoffman et al., 1987), a sarcolemma-associated cytoplasmic protein critical for maintaining sarcolemmal integrity of myofibers (Durbeej and Campbell, 2002). Minimal levels of mechanical stress are needed to impair sarcolemmal integrity in the absence of dystrophin, resulting in recurrent rounds of myofiber damage and repair (Petrof et al., 1993). Patients suffering from DMD experience progressive loss of muscle function, eventually leading to death before the age of 30. The main skeletal muscles affected in DMD are found in the shoulder, upper limbs, hips, thighs, and calves (Emery, 2002). Life-threatening symptoms for many patients involve cardiac and respiratory failure from impairment of the heart and diaphragm muscles, respectively (Nigro et al., 1990; Stedman et al., 1991). Of note, craniofacial muscles, such as the extraocular and internal laryngeal muscles, are mostly spared in DMD with the exception of pharyngeal muscles in advanced stages of the disease (Kaminski et al., 1992; Emery, 2002; Marques et al., 2007; Shinonaga et al., 2008). The mechanism of resistance of EOM to dystrophic changes was recently addressed in irradiation studies using $m d x$ :utrophin heterozygous mice. EOMs of these mice failed to develop dystrophic phenotypes even after receiving 18 Gy gamma irradiation. This resistance to dystrophic change was attributed to the presence of multiple EOM myogenic precursor populations that prevented loss of myofiber size, suggesting that the proliferative satellite cell populations of EOM play a role in the muscle sparing of EOM in many dystrophies (McDonald et al., 2014). Satellite cell abnormalities are noted in dystrophin-deficient hindlimb muscles of both mice and humans at early stages of disease. In mouse hindlimb muscles, impaired satellite cell attachment to $m d x$ myofibers may contribute to the pre-myonecrosis myofiber hypotrophy found in early postnatal disease (Duddy et al., 2015). Furthermore, premature cell senescence is observed in cultured myoblasts isolated from limb muscles of DMD patients as early as 2 years of age, the age of typical clinical onset (Blau et al., 1983; Webster and Blau, 1990) attributed to both deficiencies in Notch signaling and telomeric shortening following repeated regenerative cycles (Mouly et al., 2005; Sacco et al., 2010; Jiang et al., 2014).

\section{Limb-Girdle Muscular Dystrophy}

Limb-girdle muscular dystrophies (LGMD) are associated with mutations of more than 20 different genes in both muscle-specific and ubiquitously expressed genes with a range of molecular functions (Vieira et al., 2014). These include sarcomere proteins (titin), sarcolemmal proteins (sarcoglycan), glycosyltransferases (fukutin), nuclear envelope proteins (lamin $\mathrm{A} / \mathrm{C}$ ), and RNA-processing proteins (HNRPDL), to name a few. Intriguingly, despite the vast etiological variation, all mutations elicit dystrophic changes in muscles of the upper limb, shoulder, chest, hip, and upper leg (Broglio et al., 2010; Mitsuhashi and Kang, 2012). Satellite cell involvement has been implicated in some LGMDs. Biopsies from LGMD2A patients demonstrated a decrease in miR-1 and miR206, microRNAs involved in facilitating satellite cell differentiation that correlated with an increased Pax7+ population. Despite the increased Pax7+ population, regeneration was impaired and fibrosis elevated, suggesting an impairment of satellite cell transition from proliferation to differentiation could be contributing to the pathology of LGMD2A (Rosales et al., 2013). In contrast, decreased satellite cell numbers were reported in patients with $\alpha-, \beta$-, or $\gamma$-sarcoglycan mutations (LGMD2D, $2 \mathrm{E}$, and $2 \mathrm{C}$, respectively) when compared to Becker muscular dystrophy patient samples (Higuchi et al., 1999). Additionally, murine POMGnT1-null myoblasts (representative of LGMD2O) demonstrated impaired proliferation in vitro (Yoshida et al., 2001; Miyagoe-Suzuki et al., 2009). In a mouse model for LGMD2H, knockout of E3 ubiquitin ligase tripartite motifcontaining 32 (TRIM32) resulted in satellite cell senescence both in vitro and in vivo (Kudryashova et al., 2012; Mokhonova et al., 2015). Interestingly, pharmacologic induction of follistatin expression in satellite cells using the deacetylase inhibitor, trichostatin $\mathrm{A}$, has proved beneficial in restoring myofiber size in $\alpha$-sarcoglycan-deficient LGMD in vivo (Minetti et al., 2006). Of note, in vitro treatment of $\alpha$-sarcoglycan-deficient murine satellite cells with trichostatin A resulted in hypernucleated myotubes, suggesting a pharmacologic enhancement of myoblast differentiation/fusion (Minetti et al., 2006). It remains to be seen if other pharmacolgic approaches that alter satellite cell function might also benefit LGMD patients with other mutations.

\section{Emery-Dreifuss Muscular Dystrophy}

Emery-Dreifuss muscular dystrophy results in progressive weakness of the shoulder, upper limb, and calf muscles of patients. The most common forms of this dystrophy are caused by mutations in the ubiquitously expressed nuclear envelope proteins emerin, lamin A, or lamin C (Helbling-Leclerc et al., 2002). Why skeletal and cardiac muscles are preferentially affected in this disease, is still unclear. Patients with EmeryDreifuss MD can have severe cardiac pathology occurring as early as 30 years of age (Vohanka et al., 2001; Emery, 2002; Broglio et al., 2010). In vitro studies using primary muscle cultures from $\mathrm{Lmna}^{-/-}$knockout mice, overexpression of mutant lamin $\mathrm{A}^{\mathrm{R} 453 \mathrm{~W}}$, or RNAi knockdown of emerin demonstrated defects in myoblast differentiation (Favreau et al., 2004; Frock et al., 2006). In a recent study, in vitro culture of patient-derived myoblasts lacking emerin demonstrated enhanced proliferation 
with spontaneous differentiation, compared to control myoblasts, thus suggesting that satellite cell impairment could play a role in Emery-Dreifuss MD (Meinke et al., 2015).

\section{Facioscapulohumeral Muscular Dystrophy}

Facioscapulohumeral muscular dystrophy (FSHD) is named for the muscles mainly affected in the disease, facial, shoulder, and upper arm muscles, but foot and pelvic-girdle muscles can also be affected (Tawil and Van Der Maarel, 2006). Of the dystrophies affecting craniofacial muscles, FSHD carries the best prognosis for long-term survival, as it is a slowly progressive disease that rarely affects the heart or the ability to breathe (Tawil and Van Der Maarel, 2006). The causative deletion for FSHD type 1 (FSHD1) occurs in the subtelomeric region of chromosome 4, which can induce the expression of genes such as FSHD region gene 1 (FGR1), FGR2, ANT1, DUX4, and DUX4c (Gabellini et al., 2002; Dixit et al., 2007; Ansseau et al., 2009; Bodega et al., 2009; Snider et al., 2010). The pathogenic contributions of these genes to FSHD are still being dissected. However, evidence for satellite cell involvement in FSHD1 is growing. DUX4 expression in cultured myoblasts inhibited myogenic differentiation by repression of Myf5 and MyoD (Bosnakovski et al., 2008a,b, 2009), while overexpression of DUX4 was toxic to myoblasts in vitro (Kowaljow et al., 2007). In contrast, overexpression of DUX4c stimulated myoblast proliferation but inhibited differentiation in vitro (Bosnakovski et al., 2008a; Ansseau et al., 2009). Additionally, FGR1 overexpression impaired myoblast proliferation as well as myoblast fusion (Chen et al., 2011; Feeney et al., 2015). Primary myoblasts collected from affected thigh muscles of a transgenic mouse overexpressing FGR1 produced smaller clonal colonies than myoblasts derived from the unaffected diaphragm muscle (Chen et al., 2011). Taken together, these results indicate that satellite cells could play a direct role in FSHD1 pathology. The mechanism(s) underlying the muscle specificity of these altered myogenic phenotypes remains to be determined.

\section{Myotonic Dystrophy}

Myotonic dystrophy (DM) is a complex, multisystemic group of dystrophies that genetically arise from untranslated repeat nucleotide expansions of two separate genes, dystophia myotonic protein kinase (DMPK) and zinc finger protein 9 (ZNF9) (Day and Ranum, 2005). A (CTG) $80-4000$ repeat in the $3^{\prime}$ untranslated region of $D M P K$ is present in patients with myotonic dystrophy type 1 (DM1). The expanded regions of $D M P K$ transcripts result in altered RNA biogenesis and processing of multiple transcripts, in part, by the sequestration of the splicing factor muscle blind (MBNL1) and stabilization of CUG-binding protein 1 (CUGBP1; Mastroyiannopoulos et al., 2010). In myotonic dystrophy type 2 (DM2), up to 75-11,000 repeat expansions of $(\mathrm{TG})_{\mathrm{n}}(\mathrm{TCTG})_{\mathrm{n}}(\mathrm{CCTG})_{\mathrm{n}}$ reside in intron 1 of ZNF9 (Day and Ranum, 2005), dysregulating alternative slicing as well as protein production by sequestration of the $20 \mathrm{~S}$ proteasome (Salisbury et al., 2009). While DM1 and DM2 result from distinct genetic mutations, the biological consequences are similar as myotonia, muscular dystrophy, muscle pain, cataracts, cardiac arrhythmias, insulin insensitivity, and diabetes, hypogammaglobulinemia, and testicular failure occur in both (Schoser and Timchenko, 2010). DM affects muscles of the eyelid, face, neck, lower arms, and legs, diaphragm, and intercostal muscles (Batten and Gibb, 1909; Zifko et al., 1996). However, DM1 is associated with muscle weakness and atrophy in the lower limb muscles, while in DM2 the disease is more predominant in the upper limbs (Tieleman et al., 2012). Life-threatening conditions involving cardiac disease, respiratory failure, and difficulties in swallowing can occur (Zifko et al., 1996; Tieleman et al., 2009, 2012). Satellite cell number, proliferation and differentiation are differentially altered in DM1 patients. Decreased satellite cell numbers may result from induced autophagic processes in DM1 myoblasts (Beffy et al., 2010). Cultured myoblasts, obtained from affected lower limb muscles, proliferated less compared to unaffected upper limb muscle cultures derived from the same patients (Thornell et al., 2009). Enhanced expression of prostaglandin E2 by DM1 myoblasts inhibited differentiation and fusion in an autocrine manner (Beaulieu et al., 2012). Additionally, the p16-pathway induced premature senescence in DM1 myoblasts (Bigot et al., 2009). Satellite cells have also been implicated in DM2 pathology. For example, satellite cells underwent premature senescence in DM2 patients, but in a non-p16 dependent manner through a telomere-driven pathway (Malatesta et al., 2011; Renna et al., 2014). Impairment of satellite cells could be a major pathologic determinant in myotonic dystrophies.

\section{Oculopharyngeal Muscular Dystrophy}

Oculopharyngeal muscular dystrophy (OPMD) is an autosomal dominant disease, which typically affects people older than 50 years of age (Abu-Baker and Rouleau, 2007; Messaed and Rouleau, 2009). An aberrant expansion of alanines in the $\mathrm{N}$-terminus of poly adenosine binding protein nuclear one (PABPN1) is the underlying cause of this presently incurable disease (Brais et al., 1998; Abu-Baker and Rouleau, 2007; Messaed and Rouleau, 2009). PABPN1 is a ubiquitously expressed protein that plays key roles in RNA biogenesis (Banerjee et al., 2013). The endogenous protein contains a 10 -alanine repeat at its $\mathrm{N}$-terminus, but expansions resulting in 12-18 alanines are reported in OPMD patients (Brais et al., 1998; Abu-Baker and Rouleau, 2007; Messaed and Rouleau, 2009; Jouan et al., 2014). Muscle weakness and dystrophy occur preferentially in craniofacial skeletal muscles including the upper eye-lid, pharynx, EOMs, and tongue with weakness in upper limb muscles developing later in the disease (Emery, 2002; Abu-Baker and Rouleau, 2007; Messaed and Rouleau, 2009).

The major life-threatening difficulty for OPMD patients is the resultant dysphagia, or impairments in swallowing (Périé et al., 2006). Pharyngeal muscles of the nasal, oral, and laryngeal pharynxes are essential components of the swallow reflex (Miller, 2002; Ertekin and Aydogdu, 2003; Miller, 2008), which prevents aspiration of food and water into the trachea and lungs and the formation of life-threatening pneumonia (Martin et al., 1994; Prasse and Kikano, 2009). Of note, decreased proliferation of pharyngeal satellite cells isolated from OPMD patients was observed in vitro (Périé et al., 2006). In transgenic mice that overexpress wild-type $P A B P N 1$ specifically in skeletal muscle, increased numbers of myofibers with central nuclei suggested 
a positive effect of wild-type PABPN1 on satellite cell fusion in vivo (Randolph et al., 2014). Together, the above studies suggest that PABPN1 plays a critical role in pharyngeal satellite cell myogenesis and mutations in this protein may contribute to satellite cell impairment in OPMD patients.

Results from recent clinical trials provide preliminary evidence for the use of satellite cell transplantation as a therapeutic treatment for dysphagic OPMD patients. Phase I/IIa clinical trials were performed with dysphagic OPMD patients in which myoblasts obtained from unaffected skeletal muscles were amplified in culture and transplanted into cricopharyngeal muscles following surgical treatment of the cricopharyngeal muscle. Patients receiving injections of larger numbers of myoblasts into the cricopharyngeal area demonstrated significant improvement in swallowing over a 2-years period (Perie et al., 2014), thus providing experimental support for the use of satellite cell-based therapies for OPMD patients.

\section{Congenital Muscular Dystrophies}

Congenital muscular dystrophies (CMD) represent a large group of congenital onset muscle diseases. While this group of muscle diseases has been widely studied, satellite cell involvement has only been implicated in the pathology of two forms to date: collagen VI-related myopathies (COL6-RD) and selenoprotein $\mathrm{N}$-related myopathies (SEPN1-RM). COL6-RD include Ullrich $\mathrm{MD}$ and Bethlem myopathy and arise from mutations in COL6A1, COL6A2, or COL6A3 (Bonnemann et al., 2014). Muscle weakness occurs in distal limb, neck flexor muscles, lumbar, intercostals, and diaphragm, as well as proximal limb muscles such as the quadriceps, biceps and triceps (Haq et al., 1999; Camacho Vanegas et al., 2001; Quijano-Roy et al., 2012). When human biopsy samples were examined for changes in $\mathrm{Pax}^{+}$satellite cell numbers in normal verses Ullrich MD, no changes were observed (Paco et al., 2012). However, in Col6a1 knockout mice, satellite cell self-renewal was impaired following multiple bouts of induced injury while satellite cell numbers were maintained in Col6a1-/- mice when treated with cyclosporin A (Urciuolo et al., 2013; Gattazzo et al., 2014). Whether these results are recapitulated in satellite cells from Ullrich MD patients has yet to be determined. Rigid spine syndrome related to SEPN1 is a CMD within the SEPN1-related myopathies. Affected muscles include the thigh, gluteus maximus, paravertebral, intercostal, and sternocleidomastoid muscles (Quijano-Roy et al., 2012). Studies examining satellite cells in Sepn1-/- mice revealed decreased satellite cell numbers, impaired self-renewal, enhanced

\section{References}

Abmayr, S. M., and Pavlath, G. K. (2012). Myoblast fusion: lessons from flies and mice. Development 139, 641-656. doi: 10.1242/dev. 068353

Abu-Baker, A., and Rouleau, G. A. (2007). Oculopharyngeal muscular dystrophy: recent advances in the understanding of the molecular pathogenic mechanisms and treatment strategies. Biochim. Biophys. Acta 1772, 173-185. doi: 10.1016/j.bbadis.2006.10.003

Anraku, M., and Shargall, Y. (2009). Surgical conditions of the diaphragm: anatomy and physiology. Thorac. Surg. Clin. 19, 419-429,v. doi: 10.1016/j.thorsurg.2009.08.002 satellite cell proliferation, and exhaustion of the satellite cell pool following one round of regeneration (Castets et al., 2011). These studies suggest a potential role for satellite cells in the pathology of some CMDs. Further studies are needed to determine if satellite cells would be beneficial therapeutic targets for CMD patients.

\section{Summary}

Skeletal muscles are a highly diverse and dynamic group of tissues. As discussed, many factors contribute to skeletal muscle diversity including embryologic origin, gene expression, and functional/metabolic requirements. Such diversity likely contributes to the pathologic sensitivities of different skeletal muscles to aging and disease. Unfortunately, little is known about the effects of age or disease on non-limb muscles as a whole or what factors predispose them to the effects of pathologic conditions. Additionally, satellite cells could serve as pathologic determinants in some dystrophies; however, our knowledge of non-limb satellite cells and their role in muscle biology is severely lacking. Recognizing and elucidating the distinct differences in satellite cell biology between different skeletal muscles could be the key to unraveling the conundrum of muscle specificity between the various MDs. This review highlights the potential benefit of exploring satellite cell biology of non-limb skeletal muscles for the development of novel therapeutic approaches for patients suffering from MDs.

\section{Author Contributions}

MR: Conception and design, financial support, collection, and assembly of data, manuscript writing, final approval of manuscript.

GP: Conception and design, financial support, administrative support, collection, and assembly of data, manuscript writing, final approval of manuscript.

\section{Acknowledgments}

This work was supported by National Institute of Health grants AR061987 (GP) and DC012225 (MR).

Ansseau, E., Laoudj-Chenivesse, D., Marcowycz, A., Tassin, A., Vanderplanck, C., Sauvage, S., et al. (2009). DUX4c is up-regulated in FSHD. It induces the MYF5 protein and human myoblast proliferation. PLoS ONE 4:e7482. doi: 10.1371/journal.pone.00 07482

Apponi, L. H., Leung, S. W., Williams, K. R., Valentini, S. R., Corbett, A. H., and Pavlath, G. K. (2010). Loss of nuclear poly(A)-binding protein 1 causes defects in myogenesis and mRNA biogenesis. Hum. Mol. Genet. 19, 1058-1065. doi: $10.1093 / \mathrm{hmg} / \mathrm{ddp} 569$

Babiuk, R. P., Zhang, W., Clugston, R., Allan, D. W., and Greer, J. J. (2003). Embryological origins and development of the rat diaphragm. J. Comp. Neurol. 455, 477-487. doi: 10.1002/cne.10503 
Banerjee, A., Apponi, L. H., Pavlath, G. K., and Corbett, A. H. (2013). PABPN1: molecular function and muscle disease. FEBS J. 280, 4230-4250. doi: $10.1111 /$ febs. 12294

Barro, M., Carnac, G., Flavier, S., Mercier, J., Vassetzky, Y., and Laoudj-Chenivesse, D. (2010). Myoblasts from affected and nonaffected FSHD muscles exhibit morphological differentiation defects. J. Cell. Mol. Med. 14, 275-289. doi: 10.1111/j.1582-4934.2008.00 368.x

Batten, F. E., and Gibb, H. P. (1909). Myotonia atrophica. Brain 32, 187-205. doi: 10.1093/brain/32.2.187

Beauchamp, J. R., Heslop, L., Yu, D. S., Tajbakhsh, S., Kelly, R. G., Wernig, A., et al. (2000). Expression of CD34 and Myf5 defines the majority of quiescent adult skeletal muscle satellite cells. J. Cell Biol. 151, 1221-1234. doi: 10.1083/jcb.151.6.1221

Beaulieu, D., Thebault, P., Pelletier, R., Chapdelaine, P., Tarnopolsky, M., Furling, D., et al. (2012). Abnormal prostaglandin E2 production blocks myogenic differentiation in myotonic dystrophy. Neurobiol. Dis. 45, 122-129. doi: 10.1016/j.nbd.2011.06.014

Beffy, P., Del Carratore, R., Masini, M., Furling, D., Puymirat, J., Masiello, P., et al. (2010). Altered signal transduction pathways and induction of autophagy in human myotonic dystrophy type 1 myoblasts. Int. J. Biochem. Cell Biol. 42, 1973-1983. doi: 10.1016/j.biocel.2010.08.010

Bigot, A., Klein, A. F., Gasnier, E., Jacquemin, V., Ravassard, P., Butler-Browne, G., et al. (2009). Large CTG repeats trigger p16-dependent premature senescence in myotonic dystrophy type 1 muscle precursor cells. Am. J. Pathol. 174, 1435-1442. doi: 10.2353/ajpath.2009.080560

Bione, S., Maestrini, E., Rivella, S., Mancini, M., Regis, S., Romeo, G., et al. (1994). Identification of a novel X-linked gene responsible for Emery-Dreifuss muscular dystrophy. Nat. Genet. 8, 323-327. doi: 10.1038/ng1294-323

Blanco-Bose, W. E., Yao, C. C., Kramer, R. H., and Blau, H. M. (2001). Purification of mouse primary myoblasts based on alpha 7 integrin expression. Exp. Cell Res. 265, 212-220. doi: 10.1006/excr.2001.5191

Blau, H. M., Webster, C., and Pavlath, G. K. (1983). Defective myoblasts identified in Duchenne muscular dystrophy. Proc. Natl. Acad. Sci. U.S.A. 80, 4856-4860. doi: $10.1073 /$ pnas.80.15.4856

Bodega, B., Ramirez, G. D., Grasser, F., Cheli, S., Brunelli, S., Mora, M., et al. (2009). Remodeling of the chromatin structure of the facioscapulohumeral muscular dystrophy (FSHD) locus and upregulation of FSHD-related gene 1 (FRG1) expression during human myogenic differentiation. BMC Biol. 7:41. doi: 10.1186/1741-7007-7-41

Bonne, G., Di Barletta, M. R., Varnous, S., Becane, H. M., Hammouda, E. H., Merlini, L., et al. (1999). Mutations in the gene encoding lamin A/C cause autosomal dominant Emery-Dreifuss muscular dystrophy. Nat. Genet. 21, 285288. doi: $10.1038 / 6799$

Bonnemann, C. G., Wang, C. H., Quijano-Roy, S., Deconinck, N., Bertini, E., Ferreiro, A., et al. (2014). Diagnostic approach to the congenital muscular dystrophies. Neuromuscul. Disord. 24, 289-311. doi: 10.1016/j.nmd.2013.12.011

Borello, U., Berarducci, B., Murphy, P., Bajard, L., Buffa, V., Piccolo, S., et al. (2006). The Wnt/beta-catenin pathway regulates Gli-mediated Myf5 expression during somitogenesis. Development 133, 3723-3732. doi: 10.1242/dev.02517

Borycki, A. G., Brunk, B., Tajbakhsh, S., Buckingham, M., Chiang, C., and Emerson, C. P. Jr. (1999). Sonic hedgehog controls epaxial muscle determination through Myf5 activation. Development 126, 4053-4063.

Bosnakovski, D., Daughters, R. S., Xu, Z., Slack, J. M., and Kyba, M. (2009). Biphasic myopathic phenotype of mouse DUX, an ORF within conserved FSHD-related repeats. PLoS ONE 4:e7003. doi: 10.1371/journal.pone.00 07003

Bosnakovski, D., Lamb, S., Simsek, T., Xu, Z., Belayew, A., Perlingeiro, R., et al. (2008a). DUX4c, an FSHD candidate gene, interferes with myogenic regulators and abolishes myoblast differentiation. Exp. Neurol. 214, 87-96. doi: 10.1016/j.expneurol.2008.07.022

Bosnakovski, D., Xu, Z., Gang, E. J., Galindo, C. L., Liu, M., Simsek, T., et al. (2008b). An isogenetic myoblast expression screen identifies DUX4mediated FSHD-associated molecular pathologies. EMBO J. 27, 2766-2779. doi: 10.1038/emboj.2008.201

Brais, B., Bouchard, J. P., Xie, Y. G., Rochefort, D. L., Chrétien, N., Tomé, F. M., et al. (1998). Short GCG expansions in the PABP2 gene cause oculopharyngeal muscular dystrophy. Nat. Genet. 18, 164-167. doi: 10.1038/ng0298-164
Broglio, L., Tentorio, M., Cotelli, M. S., Mancuso, M., Vielmi, V., Gregorelli, V., et al. (2010). Limb-girdle muscular dystrophy-associated protein diseases. Neurologist 16, 340-352. doi: 10.1097/NRL.0b013e3181d35b39

Brown, C. B., Engleka, K. A., Wenning, J., Min Lu, M., and Epstein, J. A. (2005). Identification of a hypaxial somite enhancer element regulating Pax3 expression in migrating myoblasts and characterization of hypaxial muscle Cre transgenic mice. Genesis 41, 202-209. doi: 10.1002/gene.20116

Burke, A. C., and Nowicki, J. L. (2003). A new view of patterning domains in the vertebrate mesoderm. Dev. Cell 4, 159-165. doi: 10.1016/S1534-5807(03)0 0033-9

Camacho Vanegas, O., Bertini, E., Zhang, R. Z., Petrini, S., Minosse, C., Sabatelli, P., et al. (2001). Ullrich scleroatonic muscular dystrophy is caused by recessive mutations in collagen type VI. Proc. Natl. Acad. Sci. U.S.A. 98, 7516-7521. doi: 10.1073/pnas. 121027598

Castets, P., Bertrand, A. T., Beuvin, M., Ferry, A., Le Grand, F., Castets, M., et al. (2011). Satellite cell loss and impaired muscle regeneration in selenoprotein $\mathrm{N}$ deficiency. Hum. Mol. Genet. 20, 694-704. doi: 10.1093/hmg/ddq515

Chang, N. C., and Rudnicki, M. A. (2014). Satellite cells: the architects of skeletal muscle. Curr. Top. Dev. Biol. 107, 161-181. doi: 10.1016/B978-0-12-4160224.00006-8

Chen, S. C., Frett, E., Marx, J., Bosnakovski, D., Reed, X., Kyba, M., et al. (2011). Decreased proliferation kinetics of mouse myoblasts overexpressing FRG1. PLOS ONE 6:e19780. doi: 10.1371/journal.pone.0019780

Christ, B., and Ordahl, C. P. (1995). Early stages of chick somite development. Anat. Embryol. 191, 381-396. doi: 10.1007/BF00304424

Christiansen, S. P., and McLoon, L. K. (2006). The effect of resection on satellite cell activity in rabbit extraocular muscle. Invest. Ophthalmol. Vis. Sci. 47, 605-613. doi: 10.1167/iovs.05-1069

Collins, C. A., Olsen, I., Zammit, P. S., Heslop, L., Petrie, A., Partridge, T. A., et al. (2005). Stem cell function, self-renewal, and behavioral heterogeneity of cells from the adult muscle satellite cell niche. Cell 122, 289-301. doi: 10.1016/j.cell.2005.05.010

Cooper, R. N., Tajbakhsh, S., Mouly, V., Cossu, G., Buckingham, M., and ButlerBrowne, G. S. (1999). In vivo satellite cell activation via Myf5 and MyoD in regenerating mouse skeletal muscle. J. Cell Sci. 112(Pt 17), 2895-2901.

Cornelison, D. D., Filla, M. S., Stanley, H. M., Rapraeger, A. C., and Olwin, B. B. (2001). Syndecan-3 and syndecan-4 specifically mark skeletal muscle satellite cells and are implicated in satellite cell maintenance and muscle regeneration. Dev. Biol. 239, 79-94. doi: 10.1006/dbio.2001.0416

Cornelison, D. D., and Wold, B. J. (1997). Single-cell analysis of regulatory gene expression in quiescent and activated mouse skeletal muscle satellite cells. Dev. Biol. 191, 270-283. doi: 10.1006/dbio.1997.8721

Couly, G. F., Coltey, P. M., and Le Douarin, N. M. (1992). The developmental fate of the cephalic mesoderm in quail-chick chimeras. Development 114, 1-15.

Czajkowski, M. T., Rassek, C., Lenhard, D. C., Brohl, D., and Birchmeier, C. (2014). Divergent and conserved roles of Dll1 signaling in development of craniofacial and trunk muscle. Dev. Biol. 395, 307-316. doi: 10.1016/j.ydbio.2014.09.005

Day, J. W., and Ranum, L. P. (2005). Genetics and molecular pathogenesis of the myotonic dystrophies. Curr. Neurol. Neurosci. Rep. 5, 55-59. doi: 10.1007/s11910-005-0024-1

Day, K., Shefer, G., Richardson, J. B., Enikolopov, G., and Yablonka-Reuveni, Z. (2007). Nestin-GFP reporter expression defines the quiescent state of skeletal muscle satellite cells. Dev. Biol. 304, 246-259. doi: 10.1016/j.ydbio.2006. 12.026

Decary, S., Hamida, C. B., Mouly, V., Barbet, J. P., Hentati, F., and ButlerBrowne, G. S. (2000). Shorter telomeres in dystrophic muscle consistent with extensive regeneration in young children. Neuromuscul. Disord. 10, 113-120. doi: 10.1016/S0960-8966(99)00093-0

Dixit, M., Ansseau, E., Tassin, A., Winokur, S., Shi, R., Qian, H., et al. (2007). DUX4, a candidate gene of facioscapulohumeral muscular dystrophy, encodes a transcriptional activator of PITX1. Proc. Natl. Acad. Sci. U.S.A. 104, 1815718162. doi: 10.1073/pnas.0708659104

Donghui, C., Shicai, C., Wei, W., Fei, L., Jianjun, J., Gang, C., et al. (2010). Functional modulation of satellite cells in long-term denervated human laryngeal muscle. Laryngoscope 120, 353-358. doi: 10.1002/lary.20796

Donner, M. W., Bosma, J. F., and Robertson, D. L. (1985). Anatomy and physiology of the pharynx. Gastrointest. Radiol. 10, 196-212. doi: 10.1007/BF018 93103 
Duddy, W., Duguez, S., Johnston, H., Cohen, T. V., Phadke, A., GordishDressman, H., et al. (2015). Muscular dystrophy in the mdx mouse is a severe myopathy compounded by hypotrophy, hypertrophy and hyperplasia. Skelet. Muscle 5, 16. doi: 10.1186/s13395-015-0041-y

Durbeej, M., and Campbell, K. P. (2002). Muscular dystrophies involving the dystrophin-glycoprotein complex: an overview of current mouse models. Curr. Opin. Genet. Dev. 12, 349-361. doi: 10.1016/S0959-437X(02)00309-X

Dutta, C. R., and Basmajian, J. V. (1960). Gross and histological structure of the pharyngeal constrictors in the rabbit. Anat. Rec. 137, 127-134. doi: 10.1002/ar.1091370208

Ekberg, O., Ekman, M., Eriksson, L. I., Malm, R., Sundman, E., and Arner, A. (2009). An in vitro model for studying neuromuscular transmission in the mouse pharynx. Dysphagia 24, 32-39. doi: 10.1007/s00455-008-9168-x

Emery, A. E. H. (2002). The muscular dystrophies. Lancet 359, 687-695. doi: 10.1016/S0140-6736(02)07815-7

Ertekin, C., and Aydogdu, I. (2003). Neurophysiology of swallowing. Clin. Neurophysiol. 114, 2226-2244. doi: 10.1016/S1388-2457(03)00237-2

Favreau, C., Higuet, D., Courvalin, J. C., and Buendia, B. (2004). Expression of a mutant lamin A that causes Emery-Dreifuss muscular dystrophy inhibits in vitro differentiation of C2C12 myoblasts. Mol. Cell. Biol. 24, 1481-1492. doi: 10.1128/MCB.24.4.1481-1492.2004

Feeney, S. J., McGrath, M. J., Sriratana, A., Gehrig, S. M., Lynch, G. S., D’Arcy, C. E., et al. (2015). FHL1 reduces dystrophy in transgenic mice overexpressing FSHD muscular dystrophy region gene 1 (FRG1). PLoS ONE 10:e0117665. doi: 10.1371/journal.pone.0117665

Formicola, L., Marazzi, G., and Sassoon, D. A. (2014). The extraocular muscle stem cell niche is resistant to ageing and disease. Front. Aging Neurosci. 6:328. doi: 10.3389/fnagi.2014.00328

Frock, R. L., Kudlow, B. A., Evans, A. M., Jameson, S. A., Hauschka, S. D., and Kennedy, B. K. (2006). Lamin A/C and emerin are critical for skeletal muscle satellite cell differentiation. Genes Dev. 20, 486-500. doi: 10.1101/gad. 1364906

Fry, C. S., Lee, J. D., Mula, J., Kirby, T. J., Jackson, J. R., Liu, F., et al. (2015). Inducible depletion of satellite cells in adult, sedentary mice impairs muscle regenerative capacity without affecting sarcopenia. Nat. Med. 21, 76-80. doi: $10.1038 / \mathrm{nm} .3710$

Fukada, S., Uezumi, A., Ikemoto, M., Masuda, S., Segawa, M., Tanimura, N., et al. (2007). Molecular signature of quiescent satellite cells in adult skeletal muscle. Stem Cells 25, 2448-2459. doi: 10.1634/stemcells.2007-0019

Fukada, S., Yamaguchi, M., Kokubo, H., Ogawa, R., Uezumi, A., Yoneda, T., et al. (2011). Hesr1 and Hesr3 are essential to generate undifferentiated quiescent satellite cells and to maintain satellite cell numbers. Development 138, 46094619. doi: 10.1242/dev.067165

Furling, D., Coiffier, L., Mouly, V., Barbet, J. P., St Guily, J. L., Taneja, K., et al. (2001). Defective satellite cells in congenital myotonic dystrophy. Hum. Mol. Genet. 10, 2079-2087. doi: 10.1093/hmg/10.19.2079

Gabellini, D., Green, M. R., and Tupler, R. (2002). Inappropriate gene activation in FSHD: a repressor complex binds a chromosomal repeat deleted in dystrophic muscle. Cell 110, 339-348. doi: 10.1016/S0092-8674(02)00826-7

Gattazzo, F., Molon, S., Morbidoni, V., Braghetta, P., Blaauw, B., Urciuolo, A., et al. (2014). Cyclosporin A promotes in vivo myogenic response in collagen VI-deficient myopathic mice. Front. Aging Neurosci. 6:244. doi: 10.3389/fnagi.2014.00244

Goding, G. S. Jr., Al-Sharif, K. I., and McLoon, L. K. (2005). Myonuclear addition to uninjured laryngeal myofibers in adult rabbits. Ann. Otol. Rhinol. Laryngol. 114, 552-557. doi: 10.1177/000348940511400711

Gustafsson, M. K., Pan, H., Pinney, D. F., Liu, Y., Lewandowski, A., Epstein, D. J., et al. (2002). Myf5 is a direct target of long-range Shh signaling and Gli regulation for muscle specification. Genes Dev. 16, 114-126. doi: 10.1101/gad.940702

Haq, R. U., Speer, M. C., Chu, M. L., and Tandan, R. (1999). Respiratory muscle involvement in Bethlem myopathy. Neurology 52, 174-176. doi: 10.1212/WNL.52.1.174

Hebert, S. L., Daniel, M. L., and McLoon, L. K. (2013). The role of Pitx2 in maintaining the phenotype of myogenic precursor cells in the extraocular muscles. PLOS ONE 8:e58405. doi: 10.1371/journal.pone.0058405

Helbling-Leclerc, A., Bonne, G., and Schwartz, K. (2002). Emery-Dreifuss muscular dystrophy. Eur. J. Hum. Genet. 10, 157-161. doi: 10.1038/sj.ejhg.5200744
Higuchi, I., Kawai, H., Kawajiri, M., Fukunaga, H., Horikiri, T., Niiyama, T., et al. (1999). Statistically significant differences in the number of CD24 positive muscle fibers and satellite cells between sarcoglycanopathy and agematched Becker muscular dystrophy patients. Intern. Med. 38, 412-415. doi: 10.2169/internalmedicine.38.412

Himmelreich, H. A. (1973). [The palatopharyngeal muscle of mammals]. Gegenbaurs Morphol. Jahrb. 119, 172-212.

Hoffman, E. P., Brown, R. H. Jr., and Kunkel, L. M. (1987). Dystrophin: the protein product of the Duchenne muscular dystrophy locus. Cell 51, 919-928. doi: 10.1016/0092-8674(87)90579-4

Ikemoto, M., Fukada, S., Uezumi, A., Masuda, S., Miyoshi, H., Yamamoto, H., et al. (2007). Autologous transplantation of SM/C-2.6(+) satellite cells transduced with micro-dystrophin CS1 cDNA by lentiviral vector into mdx mice. Mol. Ther. 15, 2178-2185. doi: 10.1038/sj.mt.6300295

Ippolito, J., Arpke, R. W., Haider, K. T., Zhang, J., and Kyba, M. (2012). Satellite cell heterogeneity revealed by G-Tool, an open algorithm to quantify myogenesis through colony-forming assays. Skelet. Muscle 2, 13. doi: 10.1186/2044-504 $0-2-13$

Janssen, I., Heymsfield, S. B., Wang, Z. M., and Ross, R. (2000). Skeletal muscle mass and distribution in 468 men and women aged 18-88 yr. J. Appl. Physiol. 89, 81-88.

Jiang, C., Wen, Y., Kuroda, K., Hannon, K., Rudnicki, M. A., and Kuang, S. (2014). Notch signaling deficiency underlies age-dependent depletion of satellite cells in muscular dystrophy. Dis. Model Mech. 7, 997-1004. doi: 10.1242/dmm.01 5917

Joe, A. W., Yi, L., Natarajan, A., Le Grand, F., So, L., Wang, J., et al. (2010). Muscle injury activates resident fibro/adipogenic progenitors that facilitate myogenesis. Nat. Cell Biol. 12, 153-163. doi: 10.1038/ncb2015

Jouan, L., Rocheford, D., Szuto, A., Carney, E., David, K., Dion, P. A., et al. (2014). An 18 alanine repeat in a severe form of oculopharyngeal muscular dystrophy. Can. J. Neurol. Sci. 41, 508-511. doi: 10.1017/S0317167100018588

Kafadar, K. A., Yi, L., Ahmad, Y., So, L., Rossi, F., and Pavlath, G. K. (2009). Sca-1 expression is required for efficient remodeling of the extracellular matrix during skeletal muscle regeneration. Dev. Biol. 326, 47-59. doi: 10.1016/j.ydbio.2008.10.036

Kallestad, K. M., Hebert, S. L., McDonald, A. A., Daniel, M. L., Cu, S. R., and McLoon, L. K. (2011). Sparing of extraocular muscle in aging and muscular dystrophies: a myogenic precursor cell hypothesis. Exp. Cell Res. 317, 873-885. doi: 10.1016/j.yexcr.2011.01.018

Kaminski, H. J., al-Hakim, M., Leigh, R. J., Katirji, M. B., and Ruff, R. L. (1992). Extraocular muscles are spared in advanced Duchenne dystrophy. Ann. Neurol. 32, 586-588. doi: 10.1002/ana.410320418

Kawai, M., Saitsu, K., Yamashita, H., and Miyata, H. (2012). Age-related changes in satellite cell proliferation by compensatory activation in rat diaphragm muscles. Biomed. Res. 33, 167-173. doi: 10.2220/biomedres.33.167

Keefe, A. C., Lawson, J. A., Flygare, S. D., Fox, Z. D., Colasanto, M. P., Mathew, S. J., et al. (2015). Muscle stem cells contribute to myofibres in sedentary adult mice. Nat. Commun. 6, 7087. doi: 10.1038/ncomms8087

Kelly, R. G., Jerome-Majewska, L. A., and Papaioannou, V. E. (2004). The del22q11.2 candidate gene Tbxl regulates branchiomeric myogenesis. Hum. Mol. Genet. 13, 2829-2840. doi: 10.1093/hmg/ddh304

Kowaljow, V., Marcowycz, A., Ansseau, E., Conde, C. B., Sauvage, S., Matteotti, C., et al. (2007). The DUX4 gene at the FSHD1A locus encodes a proapoptotic protein. Neuromuscul. Disord. 17, 611-623. doi: 10.1016/j.nmd.2007. 04.002

Kuang, S., Kuroda, K., Le Grand, F., and Rudnicki, M. A. (2007). Asymmetric selfrenewal and commitment of satellite stem cells in muscle. Cell 129, 999-1010. doi: 10.1016/j.cell.2007.03.044

Kudryashova, E., Kramerova, I., and Spencer, M. J. (2012). Satellite cell senescence underlies myopathy in a mouse model of limb-girdle muscular dystrophy $2 \mathrm{H}$. J. Clin. Invest. 122, 1764-1776. doi: 10.1172/JCI59581

Kühn, U., Gündel, M., Knoth, A., Kerwitz, Y., Rüdel, S., and Wahle, E. (2009). Poly(A) tail length is controlled by the nuclear poly(A)-binding protein regulating the interaction between poly(A) polymerase and the cleavage and polyadenylation specificity factor. J. Biol. Chem. 284, 22803-22814. doi: 10.1074/jbc.M109.018226

Kumai, Y., Ito, T., Miyamaru, S., and Yumoto, E. (2007). Modulation of MyoD- and $\mathrm{Ki}-67$-positive satellite cells in the short-term denervated rat thyroarytenoid 
muscle. Laryngoscope 117, 2063-2067. doi: 10.1097/MLG.0b013e31813 $3 \mathrm{a} 13 \mathrm{c}$

LaFramboise, W. A., Guthrie, R. D., Scalise, D., Elborne, V., Bombach, K. L., Armanious, C. S., et al. (2003). Effect of muscle origin and phenotype on satellite cell muscle-specific gene expression. J. Mol. Cell. Cardiol. 35, 1307-1318. doi: 10.1016/S0022-2828(03)00245-1

Lee, K., Kletzien, H., Connor, N. P., Schultz, E., Chamberlain, C. S., and Bless, D. M. (2012). Effects of aging on thyroarytenoid muscle regeneration. Laryngoscope 122, 2800-2807. doi: 10.1002/lary.23589

Lepper, C., Partridge, T. A., and Fan, C. M. (2011). An absolute requirement for Pax7-positive satellite cells in acute injury-induced skeletal muscle regeneration. Development 138, 3639-3646. doi: 10.1242/dev.067595

Lescaudron, L., Peltekian, E., Fontaine-Perus, J., Paulin, D., Zampieri, M., Garcia, L., et al. (1999). Blood borne macrophages are essential for the triggering of muscle regeneration following muscle transplant. Neuromuscul. Disord. 9, 72-80. doi: 10.1016/S0960-8966(98)00111-4

L'Honore, A., Ouimette, J. F., Lavertu-Jolin, M., and Drouin, J. (2010). Pitx2 defines alternate pathways acting through MyoD during limb and somitic myogenesis. Development 137, 3847-3856.

MacIntosh, B. R., Gardiner, P. F., and McComas, A. J. (2006). Skeletal Muscle: Form and Function. Champaign, IL: Human Kinetics.

Malatesta, M., Giagnacovo, M., Renna, L. V., Cardani, R., Meola, G., and Pellicciari, C. (2011). Cultured myoblasts from patients affected by myotonic dystrophy type 2 exhibit senescence-related features: ultrastructural evidence. Eur. J. Histochem. 55, e26. doi: 10.4081/ejh.2011.e26

Malmgren, L. T., Fisher, P. J., Jones, C. E., Bookman, L. M., and Uno, T. (2000). Numerical densities of myonuclei and satellite cells in muscle fiber types in the aging human thyroarytenoid muscle: an immunohistochemical and stereological study using confocal laser scanning microscopy. Otolaryngol. Head Neck Surg. 123, 377-384. doi: 10.1067/mhn.2000.1 09487

Marques, M. J., Ferretti, R., Vomero, V. U., Minatel, E., and Neto, H. S. (2007). Intrinsic laryngeal muscles are spared from myonecrosis in the $\mathrm{mdx}$ mouse model of Duchenne muscular dystrophy. Muscle Nerve 35, 349-353. doi: 10.1002/mus.20697

Martin, B. J., Corlew, M. M., Wood, H., Olson, D., Golopol, L. A., Wingo, M., et al. (1994). The association of swallowing dysfunction and aspiration pneumonia. Dysphagia 9, 1-6. doi: 10.1007/BF00262751

Mastroyiannopoulos, N. P., Shammas, C., and Phylactou, L. A. (2010). Tackling the pathogenesis of RNA nuclear retention in myotonic dystrophy. Biol. Cell 102, 515-523. doi: 10.1042/BC20100040

Mathew, S. J., Hansen, J. M., Merrell, A. J., Murphy, M. M., Lawson, J. A., Hutcheson, D. A., et al. (2011). Connective tissue fibroblasts and Tcf4 regulate myogenesis. Development 138, 371-384. doi: 10.1242/dev.057463

Mauro, A. (1961). Satellite cell of skeletal muscle fibers. J. Biophys. Biochem. Cytol. 9, 493-495. doi: 10.1083/jcb.9.2.493

McCarthy, J. J., Mula, J., Miyazaki, M., Erfani, R., Garrison, K., Farooqui, A. B., et al. (2011). Effective fiber hypertrophy in satellite cell-depleted skeletal muscle. Development 138, 3657-3666. doi: 10.1242/dev.068858

McDermott, A., Gustafsson, M., Elsam, T., Hui, C. C., Emerson, C. P. Jr., and Borycki, A. G. (2005). Gli2 and Gli3 have redundant and contextdependent function in skeletal muscle formation. Development 132, 345-357. doi: 10.1242/dev.01537

McDonald, A. A., Kunz, M. D., and McLoon, L. K. (2014). Dystrophic changes in extraocular muscles after gamma irradiation in mdx:utrophin(+/-) mice. PLoS ONE 9:e86424. doi: 10.1371/journal.pone.0086424

McGeachie, J., and Allbrook, D. (1978). Cell proliferation in skeletal muscle following denervation or tenotomy. A series of autoradiographic studies. Cell Tissue Res. 193, 259-267. doi: 10.1007/BF00209039

McLennan, I. S. (1996). Degenerating and regenerating skeletal muscles contain several subpopulations of macrophages with distinct spatial and temporal distributions. J. Anat. 188(Pt 1), 17-28.

McLoon, L. K., Thorstenson, K. M., Solomon, A., and Lewis, M. P. (2007). Myogenic precursor cells in craniofacial muscles. Oral Dis. 13, 134-140.

McLoon, L. K., and Wirtschafter, J. (2002a). Activated satellite cells are present in uninjured extraocular muscles of mature mice. Trans. Am. Ophthalmol. Soc. 100, 119-123; discussion 123-114.
McLoon, L. K., and Wirtschafter, J. D. (2002b). Continuous myonuclear addition to single extraocular myofibers in uninjured adult rabbits. Muscle Nerve 25, 348-358. doi: 10.1002/mus.10056

McLoon, L. K., and Wirtschafter, J. (2003). Activated satellite cells in extraocular muscles of normal adult monkeys and humans. Invest. Ophthalmol. Vis. Sci. 44, 1927-1932. doi: 10.1167/iovs.02-0673

Meinke, P., Schneiderat, P., Srsen, V., Korfali, N., Le Thanh, P., Cowan, G. J., et al. (2015). Abnormal proliferation and spontaneous differentiation of myoblasts from a symptomatic female carrier of X-linked Emery-Dreifuss muscular dystrophy. Neuromuscul. Disord. 25, 127-136.

Merrell, A. J., Ellis, B. J., Fox, Z. D., Lawson, J. A., Weiss, J. A., and Kardon, G. (2015). Muscle connective tissue controls development of the diaphragm and is a source of congenital diaphragmatic hernias. Nat. Genet. 47, 496-504. doi: 10.1038/ng.3250

Messaed, C., and Rouleau, G. A. (2009). Molecular mechanisms underlying polyalanine diseases. Neurobiol. Dis. 34, 397-405. doi: 10.1016/j.nbd.2009.02.013

Miller, A. J. (2002). Oral and pharyngeal reflexes in the mammalian nervous system: their diverse range in complexity and the pivotal role of the tongue. Crit. Rev. Oral Biol. Med. 13, 409-425. doi: 10.1177/1544111302013 00505

Miller, A. J. (2008). The neurobiology of swallowing and dysphagia. Dev. Disabil. Res. Rev. 14, 77-86. doi: 10.1002/ddrr.12

Minetti, G. C., Colussi, C., Adami, R., Serra, C., Mozzetta, C., Parente, V., et al. (2006). Functional and morphological recovery of dystrophic muscles in mice treated with deacetylase inhibitors. Nat. Med. 12, 1147-1150. doi: $10.1038 / \mathrm{nm} 1479$

Mitsuhashi, S., and Kang, P. B. (2012). Update on the genetics of limb girdle muscular dystrophy. Semin. Pediatr. Neurol. 19, 211-218. doi: 10.1016/j.spen.2012.09.008

Mittelbronn, M., Sullivan, T., Stewart, C. L., and Bornemann, A. (2008). Myonuclear degeneration in LMNA null mice. Brain Pathol. 18, 338-343. doi: 10.1111/j.1750-3639.2008.00123.x

Miyagoe-Suzuki, Y., Masubuchi, N., Miyamoto, K., Wada, M. R., Yuasa, S., Saito, F., et al. (2009). Reduced proliferative activity of primary POMGnT1null myoblasts in vitro. Mech. Dev. 126, 107-116. doi: 10.1016/j.mod.2008. 12.001

Mokhonova, E. I., Avliyakulov, N. K., Kramerova, I., Kudryashova, E., Haykinson, M. J., and Spencer, M. J. (2015). The E3 ubiquitin ligase TRIM32 regulates myoblast proliferation by controlling turnover of NDRG2. Hum. Mol. Genet. 24, 2873-2883. doi: 10.1093/hmg/ddv049

Monaco, A. P., Bertelson, C. J., Liechti-Gallati, S., Moser, H., and Kunkel, L. M. (1988). An explanation for the phenotypic differences between patients bearing partial deletions of the DMD locus. Genomics 2, 90-95. doi: 10.1016/08887543(88)90113-9

Mootoosamy, R. C., and Dietrich, S. (2002). Distinct regulatory cascades for head and trunk myogenesis. Development 129, 573-583.

Morgan, J. E., and Zammit, P. S. (2010). Direct effects of the pathogenic mutation on satellite cell function in muscular dystrophy. Exp. Cell Res. 316, 3100-3108. doi: 10.1016/j.yexcr.2010.05.014

Motohashi, N., and Asakura, A. (2014). Muscle satellite cell heterogeneity and self-renewal. Front. Cell Dev. Biol. 2:1. doi: 10.3389/fcell.2014.00001

Mouly, V., Aamiri, A., Bigot, A., Cooper, R. N., Donna, S. Di Furling, D., et al. (2005). The mitotic clock in skeletal muscle regeneration, disease and cell mediated gene therapy. Acta Physiol. Scand. 184, 3-15. doi: 10.1111/j.1365201X.2005.01417.x

Munsterberg, A. E., Kitajewski, J., Bumcrot, D. A., McMahon, A. P., and Lassar, A. B. (1995). Combinatorial signaling by Sonic hedgehog and Wnt family members induces myogenic bHLH gene expression in the somite. Genes Dev. 9, 2911-2922. doi: 10.1101/gad.9.23.2911

Murphy, M. M., Lawson, J. A., Mathew, S. J., Hutcheson, D. A., and Kardon, G. (2011). Satellite cells, connective tissue fibroblasts and their interactions are crucial for muscle regeneration. Development 138, 3625-3637. doi: 10.1242/dev.064162

Nathan, E., Monovich, A., Tirosh-Finkel, L., Harrelson, Z., Rousso, T., Rinon, A., et al. (2008). The contribution of Islet1-expressing splanchnic mesoderm cells to distinct branchiomeric muscles reveals significant heterogeneity in head muscle development. Development 135, 647-657. doi: 10.1242/dev.007989 
Nigro, G., Comi, L. I., Politano, L., and Bain, R. J. (1990). The incidence and evolution of cardiomyopathy in Duchenne muscular dystrophy. Int. J. Cardiol. 26, 271-277. doi: 10.1016/0167-5273(90)90082-G

Noden, D. M., and Francis-West, P. (2006). The differentiation and morphogenesis of craniofacial muscles. Dev. Dyn. 235, 1194-1218. doi: 10.1002/dvdy. 20697

Noden, D. M., Marcucio, R., Borycki, A. G., and Emerson, C. P. Jr. (1999). Differentiation of avian craniofacial muscles: I. Patterns of early regulatory gene expression and myosin heavy chain synthesis. Dev. Dyn. 216, 96-112.

Nonaka, I. (1999). Distal myopathies. Curr. Opin. Neurol. 12, 493-499. doi: 10.1097/00019052-199910000-00002

Olson, E. N., and Klein, W. H. (1994). bHLH factors in muscle development: dead lines and commitments, what to leave in and what to leave out. Genes Dev. 8, 1-8. doi: 10.1101/gad.8.1.1

Ono, Y., Boldrin, L., Knopp, P., Morgan, J. E., and Zammit, P. S. (2010). Muscle satellite cells are a functionally heterogeneous population in both somite-derived and branchiomeric muscles. Dev. Biol. 337, 29-41. doi: 10.1016/j.ydbio.2009.10.005

Pacheco-Pinedo, E. C., Budak, M. T., Zeiger, U., Jørgensen, L. H., Bogdanovich, S., Schrøder, H. D., et al. (2009). Transcriptional and functional differences in stem cell populations isolated from extraocular and limb muscles. Physiol. Genomics 37, 35-42. doi: 10.1152/physiolgenomics.00051.2008

Paco, S., Ferrer, I., Jou, C., Cusi, V., Corbera, J., Torner, F., et al. (2012). Muscle fiber atrophy and regeneration coexist in collagen VI-deficient human muscle: role of calpain-3 and nuclear factor-kappaB signaling. J. Neuropathol. Exp. Neurol. 71, 894-906. doi: 10.1097/NEN.0b013e31826c6f7b

Pallafacchina, G., Blaauw, B., and Schiaffino, S. (2013). Role of satellite cells in muscle growth and maintenance of muscle mass. Nutr. Metab. Cardiovasc. Dis. 23(Suppl. 1), S12-S18. doi: 10.1016/j.numecd.2012.02.002

Pavlath, G. K., Thaloor, D., Rando, T. A., Cheong, M., English, A. W., and Zheng, B. (1998). Heterogeneity among muscle precursor cells in adult skeletal muscles with differing regenerative capacities. Dev. Dyn. 212, 495-508. doi: 10.1002/(SICI)1097-0177(199808)212:4<495::AID-AJA3 > 3.3.CO;2-I

Périé, S., Mamchaoui, K., Mouly, V., Blot, S., Bouazza, B., Thornell, L.-E., et al. (2006). Premature proliferative arrest of cricopharyngeal myoblasts in oculo-pharyngeal muscular dystrophy: therapeutic perspectives of autologous myoblast transplantation. Neuromuscul. Disord. 16, 770-781. doi: 10.1016/j.nmd.2006.07.022

Perie, S., Trollet, C., Mouly, V., Vanneaux, V., Mamchaoui, K., Bouazza, B., et al. (2014). Autologous myoblast transplantation for oculopharyngeal muscular dystrophy: a phase I/IIa clinical study. Mol. Ther. 22, 219-225. doi: $10.1038 / \mathrm{mt} .2013 .155$

Petrof, B. J., Shrager, J. B., Stedman, H. H., Kelly, A. M., and Sweeney, H. L. (1993). Dystrophin protects the sarcolemma from stresses developed during muscle contraction. Proc. Natl. Acad. Sci. U.S.A. 90, 3710-3714. doi: 10.1073/pnas.90.8.3710

Pickering, M., and Jones, J. F. (2002). The diaphragm: two physiological muscles in one. J. Anat. 201, 305-312. doi: 10.1046/j.1469-7580.2002.0 0095.x

Porter, J. D., and Baker, R. S. (1996). Muscles of a different 'color': the unusual properties of the extraocular muscles may predispose or protect them in neurogenic and myogenic disease. Neurology 46, 30-37. doi: 10.1212/WNL.46.1.30

Porter, J. D., Rafael, J. A., Ragusa, R. J., Brueckner, J. K., Trickett, J. I., and Davies, K. E. (1998). The sparing of extraocular muscle in dystrophinopathy is lost in mice lacking utrophin and dystrophin. J. Cell Sci. 111(Pt 13), 1801-1811.

Prasse, J. E., and Kikano, G. E. (2009). An overview of pediatric dysphagia. Clin. Pediatr. 48, 247-251. doi: 10.1177/0009922808327323

Quijano-Roy, S., Avila-Smirnow, D., Carlier, R. Y., and Wb-Mri muscle study group. (2012). Whole body muscle MRI protocol: pattern recognition in early onset NM disorders. Neuromuscul. Disord. 22 (Suppl. 2), S68-S84. doi: 10.1016/j.nmd.2012.08.003

Rai, M., Nongthomba, U., and Grounds, M. D. (2014). Skeletal muscle degeneration and regeneration in mice and flies. Curr. Top. Dev. Biol. 108, 247-281. doi: 10.1016/B978-0-12-391498-9.00007-3

Randolph, M. E., Luo, Q., Ho, J., Vest, K. E., Sokoloff, A. J., and Pavlath, G. K. (2014). Ageing and muscular dystrophy differentially affect murine pharyngeal muscles in a region-dependent manner. J. Physiol. 592, 5301-5315. doi: 10.1113/jphysiol.2014.280420

Randolph, M. E., Phillips, B. L., Choo, H. J., Vest, K. E., Vera, Y., and Pavlath, G. K. (2015). Pharyngeal satellite cells undergo myogenesis under basal conditions and are required for pharyngeal muscle maintenance. Stem Cells doi: 10.1002/stem.2098 [Epub ahead of print].

Relaix, F., Montarras, D., Zaffran, S., Gayraud-Morel, B., Rocancourt, D., Tajbakhsh, S., et al. (2006). Pax3 and Pax7 have distinct and overlapping functions in adult muscle progenitor cells. J. Cell Biol. 172, 91-102. doi: $10.1083 /$ jcb.200508044

Renna, L. V., Cardani, R., Botta, A., Rossi, G., Fossati, B., Costa, E., et al. (2014). Premature senescence in primary muscle cultures of myotonic dystrophy type 2 is not associated with p16 induction. Eur. J. Histochem. 58, 2444. doi: 10.4081/ejh.2014.2444

Robinson, D. O., Hammans, S. R., Read, S. P., and Sillibourne, J. (2005). Oculopharyngeal muscular dystrophy (OPMD): analysis of the PABPN1 gene expansion sequence in 86 patients reveals 13 different expansion types and further evidence for unequal recombination as the mutational mechanism. Hum. Genet. 116, 267-271. doi: 10.1007/s00439-004-1235-2

Rocheteau, P., Gayraud-Morel, B., Siegl-Cachedenier, I., Blasco, M. A., and Tajbakhsh, S. (2012). A subpopulation of adult skeletal muscle stem cells retains all template DNA strands after cell division. Cell 148, 112-125. doi: 10.1016/j.cell.2011.11.049

Rodgers, J. T., King, K. Y., Brett, J. O., Cromie, M. J., Charville, G. W., Maguire, K. K., et al. (2014). mTORC1 controls the adaptive transition of quiescent stem cells from G0 to G(Alert). Nature 510, 393-396. doi: 10.1038/nature13255

Rosales, X. Q., Malik, V., Sneh, A., Chen, L., Lewis, S., Kota, J., et al. (2013). Impaired regeneration in LGMD2A supported by increased PAX7-positive satellite cell content and muscle-specific microrna dysregulation. Muscle Nerve 47, 731-739. doi: 10.1002/mus.23669

Rosen, G. D., Sanes, J. R., LaChance, R., Cunningham, J. M., Roman, J., and Dean, D. C. (1992). Roles for the integrin VLA-4 and its counter receptor VCAM-1 in myogenesis. Cell 69, 1107-1119. doi: 10.1016/0092-8674(92)90633-N

Rubesin, S. E., Jessurun, J., Robertson, D., Jones, B., Bosma, J. F., and Donner, M. W. (1987). Lines of the pharynx. Radiographics 7, 217-237. doi: 10.1148/radiographics.7.2.3448633

Sacco, A., Mourkioti, F., Tran, R., Choi, J., Llewellyn, M., Kraft, P., et al. (2010). Short telomeres and stem cell exhaustion model Duchenne muscular dystrophy in mdx/mTR mice. Cell 143, 1059-1071. doi: 10.1016/j.cell.2010. 11.039

Salisbury, E., Schoser, B., Schneider-Gold, C., Wang, G. L., Huichalaf, C., Jin, B., et al. (2009). Expression of RNA CCUG repeats dysregulates translation and degradation of proteins in myotonic dystrophy 2 patients. Am. J. Pathol. 175, 748-762. doi: 10.2353/ajpath.2009.090047

Sambasivan, R., Gayraud-Morel, B., Dumas, G., Cimper, C., Paisant, S., Kelly, R., et al. (2009). Distinct regulatory cascades govern extraocular and pharyngeal arch muscle progenitor cell fates. Dev. Cell 16, 810-821. doi: 10.1016/j.devcel.2009.05.008

Sambasivan, R., Yao, R., Kissenpfennig, A., Wittenberghe, L. Van, Paldi, A., Gayraud-Morel, B., et al. (2011). Pax7-expressing satellite cells are indispensable for adult skeletal muscle regeneration. Development 138, 3647-3656. doi: 10.1242/dev.067587

Sato, T., Rocancourt, D., Marques, L., Thorsteinsdottir, S., and Buckingham, M. (2010). A Pax3/Dmrt2/Myf5 regulatory cascade functions at the onset of myogenesis. PLoS Genet. 6:e1000897. doi: 10.1371/journal.pgen.1000897

Schmalbruch, H. (1976). The morphology of regeneration of skeletal muscles in the rat. Tissue Cell 8, 673-692. doi: 10.1016/0040-8166(76)90039-2

Schoser, B., and Timchenko, L. (2010). Myotonic dystrophies 1 and 2: complex diseases with complex mechanisms. Curr. Genomics 11, 77-90. doi: 10.2174/138920210790886844

Schoser, B. G., and Pongratz, D. (2006). Extraocular mitochondrial myopathies and their differential diagnoses. Strabismus 14, 107-113. doi: $10.1080 / 09273970600701218$

Seale, P., Sabourin, L. A., Girgis-Gabardo, A., Mansouri, A., Gruss, P., and Rudnicki, M. A. (2000). Pax7 is required for the specification of myogenic satellite cells. Cell 102, 777-786. doi: 10.1016/S0092-8674(00)00066-0

Sherwood, R. I., Christensen, J. L., Conboy, I. M., Conboy, M. J., Rando, T. A., Weissman, I. L., et al. (2004). Isolation of adult mouse myogenic progenitors: 
functional heterogeneity of cells within and engrafting skeletal muscle. Cell 119, 543-554. doi: 10.1016/j.cell.2004.10.021

Shinin, V., Gayraud-Morel, B., Gomes, D., and Tajbakhsh, S. (2006). Asymmetric division and cosegregation of template DNA strands in adult muscle satellite cells. Nat. Cell Biol. 8, 677-687. doi: 10.1038/ncb1425

Shinners, M. J., Goding, G. S., and McLoon, L. K. (2006). Effect of recurrent laryngeal nerve section on the laryngeal muscles of adult rabbits. Otolaryngol. Head Neck Surg. 134, 413-418. doi: 10.1016/j.otohns.2005.11.037

Shinonaga, C., Fukuda, M., Suzuki, Y., Higaki, T., Ishida, Y., Ishii, E., et al. (2008). Evaluation of swallowing function in Duchenne muscular dystrophy. Dev. Med. Child Neurol. 50, 478-480. doi: 10.1111/j.1469-8749.2008.00478.x

Shuler, C. F., and Dalrymple, K. R. (2001). Molecular regulation of tongue and craniofacial muscle differentiation. Crit. Rev. Oral Biol. Med. 12, 3-17. doi: $10.1177 / 10454411010120010201$

Snider, L., Geng, L. N., Lemmers, R. J., Kyba, M., Ware, C. B., Nelson, A. M., et al. (2010). Facioscapulohumeral dystrophy: incomplete suppression of a retrotransposed gene. PLoS Genet. 6:e1001181. doi: 10.1371/journal.pgen.1001181

Stedman, H. H., Sweeney, H. L., Shrager, J. B., Maguire, H. C., Panettieri, R. A., Petrof, B., et al. (1991). The mdx mouse diaphragm reproduces the degenerative changes of Duchenne muscular dystrophy. Nature 352, 536-539. doi: $10.1038 / 352536 \mathrm{a} 0$

Stuelsatz, P., Keire, P., Almuly, R., and Yablonka-Reuveni, Z. (2012). A contemporary atlas of the mouse diaphragm: myogenicity, vascularity, and the Pax3 connection. J. Histochem. Cytochem. 60, 638-657. doi: $10.1369 / 0022155412452417$

Stuelsatz, P., Shearer, A., Li, Y., Muir, L. A., Ieronimakis, N., Shen, Q. W., et al. (2014). Extraocular muscle satellite cells are high performance myo-engines retaining efficient regenerative capacity in dystrophin deficiency. Dev. Biol. 397, 31-44. doi: 10.1016/j.ydbio.2014.08.035

Tajbakhsh, S., Rocancourt, D., Cossu, G., and Buckingham, M. (1997). Redefining the genetic hierarchies controlling skeletal myogenesis: pax- 3 and Myf- 5 act upstream of MyoD. Cell 89, 127-138.

Tamaki, T., Akatsuka, A., Ando, K., Nakamura, Y., Matsuzawa, H., Hotta, T., et al. (2002). Identification of myogenic-endothelial progenitor cells in the interstitial spaces of skeletal muscle. J. Cell Biol. 157, 571-577. doi: 10.1083/jcb.2001 12106

Tawil, R., and Van Der Maarel, S. M. (2006). Facioscapulohumeral muscular dystrophy. Muscle Nerve 34, 1-15. doi: 10.1002/mus.20522

Ternaux, J. P., and Portalier, P. (1993). Influence of tongue myoblasts on rat dissociated hypoglossal motoneurons in culture. Int. J. Dev. Neurosci. 11, 33-48. doi: 10.1016/0736-5748(93)90033-A

Thornell, L. E., Lindstom, M., Renault, V., Klein, A., Mouly, V., Ansved, T., et al. (2009). Satellite cell dysfunction contributes to the progressive muscle atrophy in myotonic dystrophy type 1. Neuropathol. Appl. Neurobiol. 35, 603-613. doi: 10.1111/j.1365-2990.2009.01014.x

Tieleman, A. A., Knuijt, S., van Vliet, J., de Swart, B. J., Ensink, R., and van Engelen, B. G. (2009). Dysphagia is present but mild in myotonic dystrophy type 2. Neuromuscul. Disord. 19, 196-198. doi: 10.1016/j.nmd.2008.12.002

Tieleman, A. A., Vinke, A., van Alfen, N., van Dijk, J. P., Pillen, S., and van Engelen, B. G. (2012). Skeletal muscle involvement in myotonic dystrophy type 2. A comparative muscle ultrasound study. Neuromuscul. Disord. 22, 492-499. doi: $10.1016 /$ j.nmd.2012.01.006

Uezumi, A., Fukada, S., Yamamoto, N., Takeda, S., and Tsuchida, K. (2010). Mesenchymal progenitors distinct from satellite cells contribute to ectopic fat cell formation in skeletal muscle. Nat. Cell Biol. 12, 143-152. doi: $10.1038 / \mathrm{ncb} 2014$

Urciuolo, A., Quarta, M., Morbidoni, V., Gattazzo, F., Molon, S., Grumati, P., et al. (2013). Collagen VI regulates satellite cell self-renewal and muscle regeneration. Nat. Commun. 4, 1964. doi: 10.1038/ncomms2964

Valdez, M. R., Richardson, J. A., Klein, W. H., and Olson, E. N. (2000). Failure of Myf5 to support myogenic differentiation without myogenin, MyoD, and MRF4. Dev. Biol. 219, 287-298. doi: 10.1006/dbio.2000.9621

Vieira, N. M., Naslavsky, M. S., Licinio, L., Kok, F., Schlesinger, D., Vainzof, M., et al. (2014). A defect in the RNA-processing protein HNRPDL causes limbgirdle muscular dystrophy 1G (LGMD1G). Hum. Mol. Genet. 23, 4103-4110. doi: $10.1093 / \mathrm{hmg} / \mathrm{ddu} 127$

Vohanka, S., Vytopil, M., Bednarik, J., Lukas, Z., Kadanka, Z., Schildberger, J., et al. (2001). A mutation in the X-linked Emery-Dreifuss muscular dystrophy gene in a patient affected with conduction cardiomyopathy. Neuromuscul. Disord. 11, 411-413. doi: 10.1016/S0960-8966(00)00206-6

Walz, P. C., Hiatt, K. K., Naidu, M., and Halum, S. L. (2008). Characterization of laryngeal muscle stem cell survival and proliferation. Laryngoscope 118, 1422-1426. doi: 10.1097/MLG.0b013e318173e188

Webster, C., and Blau, H. M. (1990). Accelerated age-related decline in replicative life-span of Duchenne muscular dystrophy myoblasts: implications for cell and gene therapy. Somat. Cell Mol. Genet. 16, 557-565. doi: 10.1007/BF01233096

Weintraub, H., Dwarki, V. J., Verma, I., Davis, R., Hollenberg, S., Snider, L., et al. (1991). Muscle-specific transcriptional activation by MyoD. Genes Dev. 5, 1377-1386. doi: 10.1101/gad.5.8.1377

White, R. B., Bierinx, A. S., Gnocchi, V. F., and Zammit, P. S. (2010). Dynamics of muscle fibre growth during postnatal mouse development. BMC Dev. Biol. 10:21. doi: $10.1186 / 1471-213 \mathrm{X}-10-21$

Winokur, S. T., Chen, Y. W., Masny, P. S., Martin, J. H., Ehmsen, J. T., Tapscott, S. J., et al. (2003). Expression profiling of FSHD muscle supports a defect in specific stages of myogenic differentiation. Hum. Mol. Genet. 12, 2895-2907. doi: $10.1093 / \mathrm{hmg} / \mathrm{ddg} 327$

Wirtschafter, J. D., Ferrington, D. A., and McLoon, L. K. (2004). Continuous remodeling of adult extraocular muscles as an explanation for selective craniofacial vulnerability in oculopharyngeal muscular dystrophy. J. Neuroophthalmol. 24, 62-67. doi: 10.1097/00041327-200403000-00013

Yoshida, A., Kobayashi, K., Manya, H., Taniguchi, K., Kano, H., Mizuno, M., et al. (2001). Muscular dystrophy and neuronal migration disorder caused by mutations in a glycosyltransferase, POMGnT1. Dev. Cell 1, 717-724. doi: 10.1016/S1534-5807(01)00070-3

Zifko, U. A., Hahn, A. F., Remtulla, H., George, C. F., Wihlidal, W., and Bolton, C. F. (1996). Central and peripheral respiratory electrophysiological studies in myotonic dystrophy. Brain 119(Pt 6), 1911-1922. doi: 10.1093/brain/119. 6.1911

Conflict of Interest Statement: The authors declare that the research was conducted in the absence of any commercial or financial relationships that could be construed as a potential conflict of interest.

Copyright $(2015$ Randolph and Pavlath. This is an open-access article distributed under the terms of the Creative Commons Attribution License (CC BY). The use, distribution or reproduction in other forums is permitted, provided the original author(s) or licensor are credited and that the original publication in this journal is cited, in accordance with accepted academic practice. No use, distribution or reproduction is permitted which does not comply with these terms. 